NBER WORKING PAPER SERIES

\title{
THE FORMATION OF INTERNATIONAL PRODUCTION AND DISTRIBUTION NETWORKS IN EAST ASIA
}

\author{
Mitsuyo Ando \\ Fukunari Kimura \\ Working Paper 10167 \\ http://www.nber.org/papers/w10167 \\ NATIONAL BUREAU OF ECONOMIC RESEARCH \\ 1050 Massachusetts Avenue \\ Cambridge, MA 02138 \\ December 2003
}

The first version of this paper was presented at the Fourteenth NBER Annual East Asian Seminar on Economics, "International Trade," held in Taipei, Taiwan on September 5-7, 2003. We thank all the conference participants for useful comments and great encouragement. The MITI (METI) database was prepared and analyzed in cooperation with the Applied Research Institute, Inc. and the Research and Statistics Department, the Minister's Secretariat, the Ministry of International Trade and Industry (currently the Ministry of Economy, Trade, and Industry), and the Government of Japan. The opinions expressed in this paper, though, are those of the authors. The views expressed herein are those of the authors and not necessarily those of the National Bureau of Economic Research.

(C)2003 by Mitsuyo Ando and Fukunari Kimura. All rights reserved. Short sections of text, not to exceed two paragraphs, may be quoted without explicit permission provided that full credit, including (C notice, is given to the source. 
The Formation of International Production and Distribution Networks in East Asia Mitsuyo Ando and Fukunari Kimura

NBER Working Paper No. 10167

December 2003

JEL No. F1, F2

\section{ABSTRACT}

The international production and distribution networks consist of vertical production chains and distribution networks extended across a number of countries. This paper claims that the international production and distribution networks in East Asia present distinctive characters in their significance in the regional economy, their geographical extensiveness involving a large number of countries in the region, and their sophistication of both intra-firm and arm's-length relationships across different firm nationalities. The paper starts from reviewing crucial changes in policy framework observed in the developing East Asian countries a decade ago and sketching the theoretical thoughts explaining the mechanics of international production and distribution networks. Then, the empirical part of the paper examines the micro data of Japanese corporate firms to make a closer look at the nature of networks through the pattern of FDI after analyzing overall trade patterns of the major East Asian countries to confirm the importance of international trade of machinery parts and components. In addition, the paper quantifies the magnitude of economic activities of Japanese firms through different channels of transactions, using the firm nationality approach. The last part of the paper discusses policy implication of the networks.

Mitsuyo Ando

Faculty of Economics

Keio University

2-15- 45 Mita

Minato-ku Tokyo

108-8345, Japan

JZT04263@nifty.ne.jp
Fukinari Kimura

Faculty of Economics

Keio University

2-15- 45 Mita

Minato-ku Tokyo

108-8345, Japan

fkimura@econ.keio.ac.jp 


\section{Introduction}

The East Asian region has continued to serve as the world's growth center for four decades. In the background of this "East Asian miracle," the World Bank (1993) emphasized the existence of well-managed macroeconomic fundamentals and wisely designed microeconomic policies. In the last decade, the East Asian economies added "the formation of international production/distribution networks" to their major characteristics.

The international production/distribution networks consist of vertical production chains extended across the countries in the region as well as distribution networks throughout the world. The major players are corporate firms belonging to the machinery industries including general machinery, electrical machinery, transport equipment, and precision machinery though some firms in other industries such as textiles and garment also develop the networks. While the formation of similar networks is observed between Germany and Hungary/Czech and between the U.S. and Mexico, the ones in East Asia are distinctive at least at this moment in time in the following characteristics: first, they have already become a substantial component of each country's economy in the region. Each country's manufacturing activities and international trade cannot be discussed without the networks anymore. Second, the networks involve a large number of countries at different income levels. Crosscountry differences in factor prices and other location advantages seem to be effectively utilized in the formation of vertical production chains. Third, the networks include both intra-firm and arm's-length relationships, partially across different firm nationalities. Multinational enterprises (MNEs) as well as indigenous firms in each country are forming sophisticated inter-firm relationships.

The formation of international production/distribution networks in East Asia was initiated by drastic changes in development strategies of each country. In the mid1980s and the early 1990s, the East Asian developing economies started applying new development strategies in which the benefit from hosting FDI is aggressively explored. The new development strategies do emphasize the utilization of market forces, but they are not simple laissez-faire policies; rather, pursue new roles of government involvement in the process of development. East Asia is presenting a model of new development strategies in the globalization era.

The development of international production/distribution networks in East 
Asia has also provided substantial impact on our academic thought on trade and FDI patterns. The traditional comparative advantage theory still has a certain explanatory power in the interpretation of across-industry location choices, based on international differences in technological level and factor prices. The enhanced importance of the trade in intermediate goods as well as the industrial clustering, however, has stimulated the development of new theoretical thoughts in international trade theory, particularly in the literature of fragmentation theory and agglomeration theory. In addition, the sophisticated pattern of intra-firm corporate structure and inter-firm relationship developed in East Asia has inspired research to incorporate the analysis of corporate behavior into international trade theory beyond the traditional approach of trade and FDI.

The purpose of this paper is to confirm the importance of international production/distribution networks in East Asia. Although it is difficult to directly observe the detailed mechanics of the networks with comprehensive statistics, there exist various side-evidences as well as theoretical discussions reinforcing the argument. The next section briefly reviews drastic changes in policy framework observed in the Southeast Asian countries and China in the latter half of the 1980s and the early 1990s. Section 3 sketches the current status of theoretical thoughts explaining the mechanics of international production/distribution networks. Then, the paper turns to statistical analysis on the characteristics of the networks in East Asia. Section 4 presents overall trade patterns of major East Asian countries and confirms the importance of machinery trade. Section 5 utilizes the micro data of Japanese corporate firms and makes a closer look at the nature of networks through the pattern of FDI. Section 6 quantifies the magnitude of economic activities of Japanese firms in different channels of transactions following the firm nationality approach proposed by Baldwin and Kimura (1998). Section 7 discusses policy implication of the networks and concludes the paper.

\section{Drastic changes in development strategies}

Why has an extensive international production/distribution networks been formulated in East Asia, and not in other regions such as Latin America? One of the crucial factors is the set of policies implemented by the East Asian developing 
economies from the mid-1980s or the early 1990s. ${ }^{1}$

Most of the East Asian economies have traditionally applied a "dual track approach," that is, an approach trying to foster both import-substituting industries and export-oriented industries at the same time. There was, however, an important difference between forerunners (i.e., Japan, Korea, and Taiwan) and latecomers (i.e., the Southeast Asian countries and China); the latter actively utilized incoming FDI not only in export-oriented industries but also in some major import-substituting industries such as automobiles, domestic electric appliances, pharmaceuticals, food processing, and others.

While the latecomer countries have maintained the dual track approach throughout their path of industrialization, they have changed the weights between import-substituting industries and export-oriented industries over time. From the 1970s to the mid-1980s, these countries introduced selective FDI primarily in importsubstituting industries. At that time, potentially competing domestic industries were insulated by policies that limit the activities of foreign companies only in geographically segregated places such as export-processing zones though FDI for export promotion was indeed invited. From 1985 or 1986 in Malaysia and Thailand and 1991 or 1992 in the Philippines, Indonesia, and China, however, they began to switch their FDI hosting policy from selective acceptance policy to basically "accept everybody" policy. They started trying to host as many foreign companies as possible and formulate industrial clusters while still keeping trade protection for import-substituting industries.

The dual trade approach requires a complicated policy package. What a country has to do to invite export-oriented foreign companies is simple though difficult to carry it out; it must provide the world's best or second best location advantages for incoming investors. Trade protection, of course, negatively affects location advantages. So as to partially neutralize negative effects of import-substituting industry protection, the Southeast Asian countries have introduced a duty drawback system, i.e., the system of refunds of duties and indirect taxes on imported inputs in export production.

\footnotetext{
${ }^{1}$ Kimura (2003) discusses new development strategies applied by the East Asian economies more in detail. Pangestu (2003) provides the summarized information on evolution in industrial policies in East Asia in the 1950s-1990s as well as policies and measures for promoting exports in Asia.
} 
Besides, various types of FDI facilitation measures are crucial to attract foreign companies. In particular, aggressive policy of inviting foreign small and medium enterprises (SMEs) effectively works in the formation of industrial clusters. These countries have concentrated their public resources on the development of economic infrastructure including roads, ports, electricity and water supply, telecommunications, and industrial estate services. At the same time, they have improved the services of FDI-hosting agencies, ending up with yielding considerable facilitation.

It does not mean that these countries give up fostering local indigenous firms. Instead of hastily providing protection for immature local entrepreneurs, however, they set a short-term priority on quickly building up a critical mass of agglomeration and hooking their economies up to international production/distribution networks by aggressively inviting foreign companies. The focus of local industry promotion is shifted to enhancing capability to penetrate into vertical production chains. Although cleaning up inefficient import-substituting industries still has to be considered, new development strategies with aggressively utilizing incoming FDI bear fruit in the Southeast Asian countries and China. This sets a sharp contrast with LDCs in other parts of the world.

\section{Supporting economic logic}

What sort of economic logic explains the mechanics of international production/distribution networks? When discussing the international division of labor, the theory of comparative advantage based on the relative cost of production in autarky is still valid in a number of circumstances. Technological gap and factor price differences explain location patterns of industries to some extent. In interpreting the mechanics of international production/distribution networks, however, at least three new lines of thought must be incorporated into our analytical framework.

The first line of thought is the fragmentation theory. It is a powerful tool when we analyze patterns of vertical FDI going to LDCs to formulate vertical production links or cross-border production sharing system. ${ }^{2}$ The traditional international trade theory primarily explains industry-wise location patterns. In East

2 As for the fragmentation theory, see Jones and Kierzkowski (1990), Arndt and Kierzkowski (2001), Deardorff (2001a), and Cheng and Kierzkowski (2001). 
Asia, however, production-process-wise location patterns were often observed. A typical example is semiconductor-related electronics industry. This industry as a whole is obviously capital-intensive or human-capital intensive, but its production activities are finely segmented and located in various places. The fragmentation theory neatly presents the logic behind such a location pattern.

Deardorff (2001a) defines fragmentation as "the splitting of a product process into two to more steps that can be undertaken in different locations but that lead to the same final product." Suppose that there is initially a big factory located in Japan taking care of all the production activities from upstream to downstream. If we carefully look at individual production blocks, however, we may find that some production blocks require close attention by technicians while others are purely laborintensive. If we can locate production blocks separately in Japan, Malaysia, and China, for instance, we may save the total production cost. Since the East Asian countries still have substantial differentials in labor costs, the concept of fragmentation across different cones formalized by Deardorff (2001b) seems to be particularly useful in understanding the nature of vertical production chains.

Fragmentation becomes economical when the cost of service links (SL) connecting production blocks (PB) is low enough. SL cost includes transport costs, telecommunication costs, and various coordination costs between PBs. SL cost heavily depends on the nature of technology in each industry. Globalization, however, reduces SL cost in general and enables firms in many industries to fragment their PBs further to reduce the total production cost. As SL tend to carry strong external economies of scale, the concentration of fragmented PB is often observed. The forces of fragmentation and agglomeration sometimes work in the opposite direction, but globalization actually accelerates both at the same time, which results in a situation where some countries significantly enjoy the fruit of globalization while others do not. ${ }^{3}$

The second line of thought is the agglomeration theory. This is an extension

\footnotetext{
${ }^{3}$ Where to locate fragmented production blocs also depends on the nature of the products. For instance, when case of parts and components are considerably standardized and the delivery timing is not too delicate, firms try to find suppliers of the cheapest products in the world. On the other hand, when parts and components are highly customized, and closer communication with suppliers is important, they would like to form industrial clusters.
} 
of international trade theory with external economies of scale while introducing the concept of "space" from city planning and other academic fields. ${ }^{4}$ Although the microfoundation of spatial agglomeration has not been fully explored, the importance of agglomeration as a source of location advantage is increasingly recognized in both theoretical and empirical literature. Economies of scale or agglomeration effects do not necessarily depend on the initial condition under autarky; in an extreme case, a country may start having agglomeration purely by chance. In this sense, the source of gains of trade in the "new" international trade theory is logically different from those in the traditional theory of comparative advantage, and such nature of the "new" theory addresses the possibility of the new role of government. Among the factors that generate location advantages for MNEs to invest, agglomeration is one of the crucial elements, particularly in LDCs. Governments in East Asia are obviously conscious of the potential role of government in formulating agglomeration.

The third line of thought is the internalization theory of corporate firms. A firm typically does not do everything from upstream to downstream. It sets its upstream-side boundary by purchasing materials or parts from other firms and determines its downstream-side boundary by selling their products to other firms or consumers. Such a boundary setting decision is here called "internalization decision." In addition, a firm cuts its internalized activities into thin slices and places these slices at appropriate places. This is called "location decision." A firm makes internalization decision and location decision at the same time, considering its own firm-specific assets such as technology and managerial know-how. Internalization may have different dimensions. For example, internalization decision would be made across different functional activities such as financial management, personnel management, R\&D activities, parts procurement, sales activities, and others.

In East Asia, particularly in China, various kinds of internalization patterns with innovative inter-firm relationships emerge in the effort of concentrating on core competences. OEM contracts, EMS firms, and contractual/ordinary processing are such examples. Such sophistication is particularly salient in machinery industries. Technological progress in the line of developing "modules" accelerates the formation of

\footnotetext{
4 As for the agglomeration theory, see Krugman $(1991,1995)$ and Fujita, Krugman, and Venables (1999).
} 
sophisticated inter-firm relationship. The international trade theory has not fully digested elements of ownership advantages and internalization advantages that Dunning's OLI theory presents yet. ${ }^{5}$ However, the importance of internalization choices cannot be neglected when the division of labor is at issue. Fragmentation theory and agglomeration theory must be combined with the internalization theory of corporate firms.

\section{Recent trade flows in East Asia}

Now let us review the trade pattern of East Asia. It is a well-known fact that the East Asian economies have rapidly developed intra-regional trade relationships since the early 1980s. METI (2003) presents some basic figures. Intra-regional trade of East Asia grew from US $\$ 104.3$ billion in 1981 to US\$333.1 billion in 1991, and then US $\$ 702.8$ billion in 2001; i.e., it increased by 3.2 times in 1981-1991 and 2.1 times in 1991-2001. Trade intensity indices among the East Asian economies also had an upward trend, suggesting the development of increasingly closer economic relationships.

Fukao, Ishido, and Ito (2003) decompose trade flows into one-way trade, vertical intra-industry trade, and horizontal intra-industry trade and compare the trade pattern in East Asia with the one in Europe. They find that international trade in East Asia has still a substantial amount of one-way trade but the share of vertical intraindustry trade rapidly increases.

On the top of these findings, we would like to claim that the most important changes in the trade pattern of the region is an explosive increase in trade of machinery parts and components. Table 1 shows the values and shares of exports/imports of machineries and the parts and components in major East Asian economies in 1996 and 2000. ${ }^{6}$ Machineries are here defined as HS 84-92; i.e., they include general machinery, electric machinery, transport equipment, and precision machinery. ${ }^{7}$ To capture the

5 As for the OLI theory, see Dunning (1993, pp. 81-). Kimura (2000, 2001) analyzes the micro data of Japanese manufacturing firms and claims that corporate structure and inter-firm relationship are jointly chosen with the location of activities.

${ }^{6}$ Due to the lack of data available from UN data sources, Table 1 and Figure 1 do not include Taiwan, which has also played an important role in developing the networks in East Asia.

${ }^{7}$ See Table A.1 for definition of parts and components in our study. 
features of the trade patterns in East Asia more vividly, Figure 1 summarizes the shares of machineries and the parts and components for economies in East Asia as well as other regions such as North/South America and Europe in 2000. Note that Figure 1 plots countries from the one with the highest share of machinery parts and components' exports, aiming at addressing the relative significance of machinery parts and components' trade among countries in various regions.

$$
\begin{aligned}
& ==\text { Table } 1== \\
& ==\text { Figure } 1==
\end{aligned}
$$

An astounding fact is that the shares of machineries in each East Asian country's total exports and imports are indeed very large. Except the cases of imports for Japan and China and exports and imports for Indonesia, the shares of machinery trade are as high as 40 percent or even higher up to 77 percent for both export and import sides. They imply how significant the machinery industries are in the East Asian economies. Furthermore, the shares of parts and components in machinery trade are also very high; they are 40 percent to 50 percent or even reach 80 percent in cases of the Southeast Asian countries, and the shares are further increasing even in the shirt period between 1996 and 2000. These suggest a large portion of back-and-forth transactions of intermediate goods in the international production/distribution networks in machinery industries, which are extended across a large number of countries at different income levels in the region.

In other regions, on the other hand, higher shares of machinery trade and those of machinery parts and components' trade are observed only for some specific countries such as Mexico, the U.S., Hungary, Czech Republic, and Germany (Figure 1). These suggest the existence of networks in machinery industries between the U.S. and Mexico and between Germany and the two East European countries but these networks are not extensively covering a number of countries. The fact that the shares of machinery exports and imports are indeed high but the share of machinery parts and components' exports is not such high in Mexico would support the evidence where Mexico imports machinery parts and components from the U.S., assembles them, and exports final goods back to the U.S., rather than developing networks across neighboring countries. 
Moreover, other countries, particularly the ones in Latin America, present by far lower shares of machinery exports than countries in East Asia. At the same time, the shares of machinery exports are much lower than the shares of machinery imports in these countries. They suggest that machinery industries are not well developed in these economies yet and they are not forming networks.

In East Asia, the trade pattern is not simple one-way trade based on international differences in resource endowments anymore. Rather, sophisticated vertical production chains as well as distribution connection are extended to regionwide networks. Fragmentation is an obvious phenomenon. The reduction of service link costs derives from technological progress in logistics and improved policy environment, which makes extensive fragmentation possible. One of the motivations for fragmentation is to take advantage of factor price differences as suggested by Deardorff (2001b). In addition, however, other elements of location advantages such as service link cost and agglomeration effects are increasingly influential in the location choices of MNEs.

Note that not all countries in East Asia are effectively connected with such networks at this moment. The CMLV (Cambodia, Myanmar, Laos, and Vietnam) countries have not been fully involved with the networks yet. These countries have substantially low wage levels but are not entirely successful in attracting labor-intensive production processes. This fact suggests that government policies to reduce service link costs and encourage agglomeration are crucially important in order for a country to hook up itself to international production/distribution networks.

\section{Evidence from the micro data of Japanese firms}

Corporate firms in the forerunners of development in the region, Japan, Korea, and Taiwan have had strong technological competitiveness in machinery manufacturing. Since machines are typically made of a large number of parts and components, the competitiveness in machines depends on both the quality/production cost of parts and components and managerial ability of vertical production networks, in which corporate firms in East Asia particularly have their strengths. When these firms became mature enough to compete in international arena, and the Southeast Asian countries and China prepared for proper policy environment in the mid-1980s and the 1990s, the formation of international production/distribution networks was a natural consequence. 
The networks consist of both intra-firm geographical extension and inter-firm business relationships. Up to the 1980s, an important component of the Japanese economic system was the subcontracting system (shitauke in Japanese) or long-term relationships between large downstream assemblers and upstream SMEs. ${ }^{8}$ However, the inter-firm relationship of Japanese firms has drastically changed since Japanese firms started to actively conduct FDI in the mid-1980s. It is often observed that both large assemblers and SMEs make FDI together to form a certain size of agglomeration in Southeast Asia or China. Even in such cases, upstream-downstream relationships become more competitive, non-exclusive ones. With strict cost consideration, many Japanese firms are now open to extend their production chains to firms with other nationalities as far as the technological level meets.

Although it is very difficult to trace the nature of such corporate relationships by statistical figures, this section attempts to present some evidence of corporate firms' behavior to understand the mechanics of international production/distribution networks in East Asia by analizing the firm-level micro data of Japanese corporate firms. Tables in this section are constructed from either of the two sets of micro data, both of which are conducted by Ministry of International Trade and Industry (MITI), Government of Japan: 1) the F/Y 1996 and F/Y 2001 Basic Survey of Business Structure and Activity and 2) the F/Y 1999 Survey (the 27th Basic Survey) of Overseas Business Activities of Japanese Companies. The first firm-level database provides detailed information on parent firms located in Japan and also the number, industry, and regional location of their foreign affiliates. In Tables 2 to 5, constructed from this database, foreign affiliates are defined as those with no less than 20 percent Japanese ownership. The second database presents information on the performance of foreign affiliates. In Table 6, obtained from this database, foreign affiliates include both "affiliates abroad" with no less than 10 percent ownership by Japanese parent firms and "affiliates of affiliates abroad" with no less than 50 percent ownership by "affiliates abroad" (call both of them "Japanese affiliates abroad" hereinafter). A more detailed explanation of these databases is given in Appendix 1.

Table 2 presents (a) the number of parent firms with foreign affiliates and the

\footnotetext{
${ }^{8}$ As for the economic interpretation of the Japanese subcontracting system, see Kimura (2002).
} 
number of foreign affiliates; (b) the number of parent firms with affiliates in East Asia and the number of affiliates in East Asia; (c) the number of parent firms with affiliates in North America and the number of affiliates in North America; and (d) the number of parent firms with affiliates in Europe and the number of affiliates in Europe, by the industry of parent firms and by the industry of affiliates in $2000 .{ }^{9}$ In $2000,3,773$ out of 27,655 firms located in Japan (in the data set) totally have 18,943 foreign affiliates. Among them, 2,994 firms have 10,224 affiliates in East Asia. That is, as many as 80 percent of the Japanese firms going abroad has at least one affiliate in East Asia, and 54 percent of the foreign affiliates of Japanese firms are located in East Asia.

\section{$==$ Table $2==$}

Japanese manufacturing parent firms, particularly machinery parent firms are active investors in East Asia; close to 70 percent of the Japanese parent firms with affiliates in East Asia are in the manufacturing sector (Industries 120 to 320) and half of them are in the machinery sector (290 to 320). The pattern observed for affiliates in East Asia by the industry of affiliates also reveals how dominant manufacturing activities are in East Asia, which is clearly different from the patterns for affiliates in North America or Europe. In East Asia, 60 percent of the affiliates in the region are manufacturing, regardless of the industries of their parent firms, while 38 percent of the affiliates in North America and 31 percent of the affiliates in Europe are. ${ }^{10}$ The number of affiliates actually increased in the five years, 1995-2000, from 9,132 to 10,224 in East Asia while the numbers decreased from 3,928 to 3,499 in North America and from 3,019 to 2,913 in Europe. Manufacturing activities are dominant and have been intensified in East Asia in terms of both Japanese parent firms and their affiliates.

Japanese SMEs with regular workers of less than 300 have greatly contributed to such expansion of manufacturing activities in East Asia by Japanese firms. Table 3 presents the number of Japanese parent firms with affiliates in East Asia, North America, and Europe in 2000 by the size of parent firms and by the number of affiliates. The

\footnotetext{
${ }^{9}$ See Table A.2 for industry classification.

${ }^{10}$ See Kimura and Ando (2003) for comparative study between Latin America and East Asia, based on the micro data of Japanese corporate firms.
} 
table shows that more than 40 percent of the Japanese firms going to East Asia are SMEs while the shares are much lower in North America and Europe. Furthermore, the fact that a considerable number of firms, including SMEs, have plural affiliates in East Asia also supports that Japanese SMEs are actively involved in manufacturing activities in the region. Such active FDI by Japanese SMEs in East Asia have contributed to forming a critical mass of industrial clusters.

\section{$==$ Table $3==$}

As suggested by Table 2, Japanese parent firms do not necessarily establish affiliates in their own industries where they have main activities. ${ }^{11}$ In general, parent firms have various activities across industries and establish foreign affiliates in order to conduct a subset of those activities. Table 4 provides the detailed information on sector switching between parent firms and their affiliates in East Asia; Table 4 (a) includes all sized Japanese firms with affiliates and Table 4 (b) focuses on SMEs. The rows denote the industry of parent firms while the columns the industry of foreign affiliates. Thus, diagonal cells of the tables indicate the number of non-sectorswitching affiliates while off-diagonal cells denote the number of sector-switching affiliates.

$==$ Table $4==$

In East Asia, 75 percent of the affiliates owned by all sized manufacturing parent firms are in the manufacturing sector. ${ }^{12}$ Among them, we observe many sectorswitching manufacturing affiliates with manufacturing parent firms (in non-diagonal cells for industries 120 to 340 in both rows and columns), in particular sector-switching machinery affiliates with manufacturing parent firms (in non-diagonal cells for industries 120 to 340 in rows and industries 290 to 320 in columns). In addition, even

\footnotetext{
${ }^{11}$ A firm often has various activities at the same time. The industrial classification of a firm located in Japan is determined by the largest activities the concerned firm conducts in terms of the value of sales.

${ }^{12}$ In the case of manufacturing SMEs, the share of manufacturing affiliates is much higher; as many as 87 percent of their affiliates are manufacturing.
} 
manufacturing SMEs have sector-switching manufacturing affiliates, particularly sectorswitching machinery affiliates in East Asia, which is not often observed in North America or Europe. Such behavior is typical in manufacturing activities aimed at supplying intermediate goods for other firms or for their own affiliates. It implies that Japanese firms have played an important role in developing vertical production networks in the region.

Moreover, manufacturing parent firms also have non-manufacturing affiliates, particularly in the wholesale trade sector. Sector-switching non-manufacturing affiliates with manufacturing parent firms (in cells for industries 120 to 340 in rows and industries 480 and others in columns) make up 25 percent of the affiliates owned by allsized manufacturing parent firms and 13 percent of the affiliates owned by manufacturing SMEs, suggesting that another strategy in East Asia is to establish global production/distribution networks by internalizing wholesale trade activities. Note that these ratios are much smaller than in North America (49 percent for all sized firms and 48 percent for SMEs) and Europe (60 percent and 51 percent).

Before moving to the performance of Japanese affiliates abroad, let us formally analyze the characteristics of Japanese parent firms going to East Asia. Table 5 reports (a) the results of logit regression analysis for Japanese parent firms in all sectors and (b) the results of Japanese manufacturing parent firms. The dependent variable for regression No.1 in both tables is whether a firm has foreign affiliate(s) or not. Similarly, the dependent variable for regression No.2/No.3/No.4 is whether a firm has affiliate(s) in East Asia/North America/Europe. The independent variables are the number of regular workers (in log), tangible assets per regular workers, foreign sales, R\&D expenditure, and advertisement expenditure. ${ }^{13}$ For the whole samples, firms with foreign affiliates are likely to have large employment size, capital-intensive technology, large foreign sales, and large R\&D expenditure. The coefficients for both the firms' size and $R \& D$ expenditure in the case of affiliates in East Asia are much smaller than those in the case of North America and Europe. It can be concluded that firms going to East Asia are relatively small as we have descriptively discussed, and thus less R\&D intensive, compared with firms going to North America or Europe.

\footnotetext{
${ }^{13}$ Note that variables for foreign sales, R\&D expenditure, and advertisement expenditure are in ratios to total sales.
} 
Table 6, in turn, focuses on the performance of Japanese affiliates in East Asia, North America, and Europe. The table presents (a) the destination of sales and (b) the origin of purchases by Japanese affiliates in East Asia. Most of the goods and services produced by Japanese affiliates in East Asia go to the local market, to Japan, or to other East Asian countries: 49.6 percent for local, 21.9 percent for Japan, and 21.2 percent for countries within the region except local and Japan. ${ }^{14}$ By-origin purchases by Japanese affiliates in East Asia also show that they purchase most goods and services from the local market (41.1 percent), or import them from Japan (33.4 percent) or from other East Asian countries (20.7 percent). Japan's share in purchases is slightly higher than in sales, probably due to the supply of complicated machinery parts and components from Japan. ${ }^{15}$ These reveal that more than 90 percent of the sales and purchases by Japanese affiliates are among the East Asian countries, including Japan, and suggest the presence of active intra-regional production networks in East Asia.

\section{$==$ Table $6==$}

In the case of North America and Europe, in contrast, sales to Japan are fairly small; 5.2 percent and 5.8 percent, respectively. In addition, more than half of the sales of the affiliates in the regions are from affiliates in non-manufacturing sector (59.2 percent for North America and 63.4 percent for Europe), particularly in wholesale trade sector (47.5 percent and 44.2 percent). This indicates that they aim to sell products in the local market or in countries nearby rather than forming vertical chains of production networks.

The empirical observation we have discussed may not directly prove the relevance of three lines of new theoretical thought. However, active FDI by Japanese SMEs, the existence of many sector-switching manufacturing affiliates, and intra-

\footnotetext{
${ }^{14}$ Contrary to popular opinion, sales to North America by Japanese affiliates in East Asia are small (3.4 percent). Sales to Europe are also small (2.6 percent).

${ }^{15}$ The share of purchases from North America is quite small.
} 
regional trade by Japanese affiliates indeed imply how such logics work in developing international production/distribution networks in East Asia.

\section{Evidence from the firm nationality approach}

The last section tried to capture the activities of Japanese firms in East Asia by analyzing affiliate holdings and by-destination sales/by-origin purchases. These statistical figures, however, does not directly indicate the magnitude of Japanese firms' activities in exporting from Japan and producing in East Asia and who is trading with whom. The amount of gross sales does not necessarily reflect the importance of each transaction since intermediate inputs embodied in traded commodities may be counted multiple times. One of the ways to quantify the importance of transactions is to introduce the concept of value added contents.

To quantify the whole Japanese firms' activities in different locations and embodied value added contents in international transactions, this section employs the firm nationality approach, which is first proposed by Baldwin and Kimura (1998) and Kimura and Baldwin (1998) in a two-country setting and is extended to a three-country setting by Kimura (1998). The three-country setting thinks of three geographical territories, i.e., Japan, Asia, ${ }^{16}$ and the rest of the world (ROW) as well as three nationals, i.e., Japanese, Asians, and foreigners (the national of ROW). "Japanese" consist of Japanese-owned firms located in Japan, households and governments located in Japan, and foreign affiliates of Japanese firms (FAJFs) located in Asia and ROW. ${ }^{17}$ Asians and foreigners are defined in the symmetric way. Three nationals reside in three different locations, and thus 9 blocks are drawn as in Figure 2. Conceptually, transactions within a block and between blocks are illustrated as 81 ( 9 times 9) arrows in total. We can, however, fill out 14 arrows of transactions because only statistical data from the Japanese side are readily available.

The numbers shown for 14 arrows in Figure 2 stand for the estimated Japanese value added contents of each transaction added at the starting point of the corresponding arrow in 2000. Table A.3 provides the summary table and the

\footnotetext{
${ }^{16}$ Asia stands for Asian countries east of Pakistan in this section.

${ }^{17}$ Note that "Japanese" in this definition is different from those on the residency basis or those in the sense of factor holders; we treat FAJF as controlled by Japanese and count the whole activities of FAJF as activities by Japanese.
} 
estimation method of each estimate. Additional explanation of estimation method and data description is given in Appendix 2 as well. Table 7 presents estimates of the value added contents embodied in sales by Japanese to Asians in Asia and to foreigners in ROW, estimated based on Table A.3.

$$
\begin{aligned}
& ==\text { Figure } 2== \\
& ==\text { Table } 7==
\end{aligned}
$$

Although these figures are only rough estimates with a number of reservations on the data set, the value added account provides useful insights on the activities of Japanese MNEs, including intra-firm and arm's length relationships. Major findings are the following three. First, activities of Japanese firms have gradually shifted from Japan to Asia. When we focus on Japanese firms who sell products to Asians in Asia, value added contents of "to produce in Japan and distributing through FAJF in Asia" and value added contents of "to produce in Asia and sell locally" increased from 1996 to 2000 (increase in the share by 2.1 percent) while the share of "to produce in Japan and export directly" decreased by 3.7 percent. $^{18}$ Also, when we compare value added contents of "to produce in Asia and sell locally" with "to produce in Japan and distributing through FAJF in Asia", the former becomes larger in 2000 though it was smaller in 1996. This implies that importance of local value added has enhanced vis-àvis inputs from Japan.

Second, international production/distribution networks consist not only of Japanese firms but also of the mixture of firms of different nationalities. When value added in exports by Japanese in Japan to Asians (Asian firms) and foreigners (MNEs other than Japanese) in Asia is compared with that to Japanese (Japanese affiliates in Asia) in Asia, for instance, the former is larger than the latter. Thus, it is not true that the activities by Japanese firms are solely based on subcontracting relationships or intrafirm relationships between Japanese parent firms and Japanese affiliates in East Asia though such activities still consist of a significant portion; rather the activities do

\footnotetext{
${ }^{18}$ The same analysis (Figure 2 and Table 7) was also conducted for 1996, but the results were omitted in the paper.
} 
include transactions with indigenous firms and MNEs in Asia. ${ }^{19}$

In addition, when we again focus on Japanese firms who sell products to Asians in Asia, the channel for direct exports to Asia from Japan is still important as the share of "to produce in Japan and export directly" suggests; 58.3 percent in 2000. In direct exports from Japan to Asia, capital goods for "Asian" firms are certainly significant. Besides, intermediate inputs, particularly machinery parts and components, for "Asian" firms are also large; combined with the information on Japan's export in Table 1, roughly one-third to half of them are machinery parts and components.

Third, the connection with North America or Europe is thin for both exports and imports. Among several channels for Japanese firms to sell products, the shares of "to produce in ROW and export to Asia" and "to produce in Asia and export to ROW" are pretty small. These low ratios imply weak connections with North America and Europe, confirming that contrary to popular opinion, sales to North America by Japanese affiliates in East Asia are small.

\section{Current policy issues}

This paper claimed the importance of international production/distribution networks in East Asia. In fact, the formation of the networks carries profound policy implication. This concluding section provides brief discussion on this matter.

The dual track approach has so far worked pretty well in East Asia. Figure 3 presents over-time changes in the customs duty import ratios in East Asian developing countries. This is the ratio of total customs duty revenue of a country to the c.i.f.based import value. It is immediately noticed that the ratios are much smaller than average tariff figures that we usually discuss as an indicator for trade barriers. Moreover, the ratios present clear decreasing trends over time. These phenomena are partly due to unilateral tariff reduction for IT-related products in the 1990s and also due to the effective usage of duty drawback system. In fact, MNEs in export-oriented

\footnotetext{
${ }^{19}$ The transactions between Japanese firms in Japan and Japanese affiliates in ROW are indeed large, but the purpose is to sell Japanese products locally (in North America or Europe) rather than contributing to forming networks. This is consistent with the facts observed in Section 5 that the large portion of affiliates in North America and Europe is in the wholesale trade sector and more than $40 \%$ of the total sales by affiliates in North America or Europe are from affiliates in the wholesale trade sector.
} 
industries are now paying very small amount of tariffs in these countries. Such a policy package has at least partially mitigated anti-export biases with trade protection for import-substituting industries and has allowed them to attract both importsubstituting FDI and export-oriented FDI so far.

$$
==\text { Figure } 3==
$$

However, further activating the international production/distribution networks requires new policy setting. First, fostering import-substituting industries was not after all very successful with a few exceptions, and the cost of protection gradually becomes unbearable. Indeed, Southeast Asian countries and China still have high tariffs for a number of import-substituting industries. To substitute imports by domestic production, governments of these countries have for long provided trade protection for domestic firms or incoming foreign companies. However, trade protection cannot still be removed because of the long-lasting poor competitiveness of these industries. The protection cost is borne by consumers and other industries including export-oriented industries. It cannot be continued forever, and policymakers gradually recognize that it is now the time to reorganize these industries in a more competitive environment. These industries include automobiles, domestic electric appliances, petrochemicals, and iron and steel.

Second, even if tariffs are properly removed, business environment of East Asia is still far from borderless. Cross-border transaction costs are high for various reasons. Physical infrastructure in transportation and telecommunications is one of the important factors to improve the business environment. Trade facilitation in customs clearance and other bureaucratic procedures is another vital element. As a more abstract form of transaction costs, legal systems and economic institutions such as standards, intellectual property rights protection, and dispute settlement facilities, are also crucial. To keep attracting FDI and encourage the formulation of agglomeration, policies beyond simple tariff removal become essential.

Third, the sophistication of networks and the development of agglomeration require extensive involvement of local indigenous firms. The focus of local industry promotion is not placed on infant industry protection for import substitution anymore. Rather, the issue is what the government can do in order to make local indigenous firms 
penetrate into international vertical production chains. Policymakers know that impatient performance requirements for foreign companies such as local contents requirement and technology transfer requirement have not worked very well. Government-financed technology development centers for local technicians have also borne lukewarm results in many cases. The governments should ultimately make effort in enhancing human resources for both entrepreneurs and engineers, but human capital development takes time. The role of government is obviously important, but there is no easy policy to reach the goal.

These three issues are, to the authors' opinion, natural policy agenda in the formation of the international production/distribution networks, and we hope that policymakers in this region have clear mind in confronting with these issues. The East Asian countries are now actively engaging the effort toward formulating regional trade arrangements. The contents of such arrangements are expected to reflect necessary policy reform in the East Asian countries.

\section{References}

Ando, Mitsuyo and Estevadeordal, Antoni. (2003) "Trade Policy Formation in Latin America and Asia-Pacific: A Comparative Analysis.” Mimeo.

Arndt, S. W., \& Kierzkowski, H. (2001). Fragmentation: New Production Patterns in the World Economy. Oxford: Oxford University Press.

Baldwin, Robert E. and Kimura, Fukunari. (1998) "Measuring U.S. International Goods and Services Transactions." In R. E. Baldwin, R. E. Lipsey, and J. D. Richardson, eds., Geography and Ownership as Bases for Economic Accounting. Chicago: The University of Chicago Press.

Cheng, Leonard K. and Kierzkowski, Henryk. (2001) Global Production and Trade in East Asia. Boston: Kluwer Academic Publishers.

Deardorff, A. V. (2001a) "Fragmentation in Simple Trade Models." North American Journal of Economics and Finance, 12: 121-137.

Deardorff, Alan V. (2001b) "Fragmentation across Cones." In Sven W. Arndt and Henryk Kierzkowski, eds., Fragmentation: New Production Patterns in the World Economy. Oxford: Oxford University Press.

Dunning, John H. (1993) Multinational Enterprises and the Global Economy. 
Wokingham: Addison-Wesley.

Fujita, Masahisa; Krugman, Paul; and Venables, Anthony J. (1999) The Spatial Economy: Cities, Regions, and International Trade. Cambridge: The MIT Press. Fukao, Kyoji; Ishido, Hikari; and Ito, Keiko. (2003) "Vertical Intra-Industry Trade and Foreign Direct Investment in East Asia.” RIETI Discussion Paper Series 03-E001.

Jones, R. W. and Kierzkowski, Henryk. (1990) “The Role of Services in Production and International Trade: A Theoretical Framework.” In Ronald W. Jones and Anne O. Krueger, eds., The Political Economy of International Trade: Essays in Honor of Robert E. Baldwin. Oxford, Basil Blackwell.

Kimura, Fukunari. (1998) "Japanese Multinationals and Regional Integration in Asia." In Kiichiro Fukasaku, Fukunari Kimura, and Shujiro Urata, eds., Asia \& Europe: Beyond Competing Regionalism. Brington: Sussex Academic Press.

Kimura, Fukunari. (2000) "Location and Internalization Decisions: Sector Switching in Japanese Outward Foreign Direct Investment." In Takatoshi Ito and Anne O. Krueger, eds, The Role of Foreign Direct Investment in East Asian Economic Development. Chicago: University of Chicago Press.

Kimura, Fukunari. (2002) "Subcontracting and the Performance of Small and Medium Firms in Japan.” Small Business Economics 18: 163-175.

Kimura, Fukunari. (2003) "Development Strategies for Economies under Globalisation: Southeast Asia as a New Development Model." Forthcoming in Tran Van Hoa and Charles Harvie, eds., New Asian Regionalism: Responses to Globalisation and Crises. London: Palgrave.

Kimura, Fukunari and Ando, Mitsuyo. (2003) "Fragmentation and Agglomeration Matter: Japanese Multinationals in Latin America and East Asia." North American Journal of Economics and Finance, Vol. 14, Issue 3: 287-317.

Kimura, Fukunari and Baldwin, Robert E. (1998) "Application of a NationalityAdjusted Net Sales and Value Added Framework: The Case of Japan.” In R. E. Baldwin, R. E. Lipsey, and J. D. Richardson, eds., Geography and Ownership as Bases for Economic Accounting. C Chicago: The University of Chicago Press.

Krugman, Paul. (1991) "Increasing Returns and Economic Geography." Journal of Political Economy 99: 183-199.

Krugman, Paul. (1995) Development, Geography, and Economic Theory. Cambridge: 
The MIT Press.

Management and Coordination Agency, Government of Japan. (1999) 1995 InputOutput Tables: Explanatory Report. Tokyo: Management and Coordination Agency, Government of Japan.

The Ministry of Economy, Trade and Industry (METI), Government of Japan. (2001)

White Paper on International Trade 2001 (Japanese version). Tokyo: METI

The Ministry of Economy, Trade and Industry (METI), Government of Japan. (2002a)

The 35th Survey of Japanese Affiliates of Foreign Firms (Japanese version).

Tokyo: Printing Office, Ministry of Finance, Government of Japan.

The Ministry of Economy, Trade and Industry (METI), Government of Japan. (2002b)

The 31th Survey of Overseas Business Activities of Japanese Companies (Japanese version). Tokyo: Printing Office, Ministry of Finance, Government of Japan.

The Ministry of Economy, Trade and Industry (METI), Government of Japan. (2003)

White Paper on International Trade 2003 (Japanese version). Tokyo: METI.

Pangestu, Mari. (2003) in Bernard Hoekman, Philip English and, Aaditya Matto eds., Development, Trade, and the WTO: A Handbook. Washington D.C.: World Bank. The World Bank. (1993) The East Asian Miracle: Economic Growth and Public Policy. Oxford: Oxford University Press. 
Appendix 1: data sources for section 5

The Basic Survey of Business Structure and Activity (Kigyo Katsudo Kihon Chosa in Japanese) is the MITI survey, first conducted for F/Y 1991, then for F/Y 1994, and annually since then. The Basic Survey has several attractive features. First, the samples in the survey are comprehensive, covering all firms with more than 50 workers, capital of more than 30 million yen, and establishments in mining, manufacturing, wholesale/retail trade, and restaurants. Foreign affiliates covered in the survey are those with no less than 20 percent Japanese ownership. Second, the ratios of questionnaire returns are high; the actual ratios are not disclosed, but are about 90 to 95 percent. Statistics collected by the Government of Japan are legally classified into two categories: designated statistics (shitei toukei) and approved statistics (shounin toukei). The Basic Survey is the first type, and thus firms in the survey must return the questionnaires under the Statistics Law. Third, it provides firm-level data rather than the data on an establishment basis. Although establishment-level data are useful in analyzing production activities, firm-level data are much more appropriate to examine corporate activities as a whole.

The Survey of Overseas Business Activities of Japanese Companies, which is also conducted by MITI, has been conducted annually since F/Y 1970. Firms targeted by the survey are those with Japanese affiliates abroad of Japanese firms, except firms in finance, insurance, or real estates. The Survey of Overseas Business Activities is of the approved type, so that the effective return ratios tend to be as low as 60 percent (in the case of the F/Y 1999 Survey, the returned ratio is 56.0 percent). As explained in section 5, Japanese affiliates abroad include both "affiliates abroad" with no less than 10 percent ownership by Japanese parent firms and "affiliates of affiliates abroad" with more than $50 \%$ ownership by such "affiliates abroad", but the survey can distinguish the former and the latter if necessary.

The industry classification used in this paper is presented in Table A.2. Since the industry classification of the Survey of Overseas Business Activities is different from that of the Basic Survey, the latter industry classification is matched with the former to make them comparable. Unfortunately, services sectors are not fully covered by both surveys.

Appendix 2: the estimation method and data sources for section 6 
The detailed estimation method is described in Table A.3. Japanese value added in exports of Japanese-owned firms is calculated by subtracting the import component in the exports. The proportion of the import component in exports (8.504\%) is obtained from Management and Coordination Agency (1999) (1995 InputOutput Tables). Exports of Japanese-owned firms are calculated by subtracting exports of JAFF from exports of Japan. The data for exports of JAFF are available from METI (2002a). Assuming that the ratio of value added to sales is the same no matter where the sales destination is, we obtain the Japanese value added in exports of Japanese-owned firms to FAJF in Asia (7,205,530 million JP Yen), to FAJF in ROW (21,084,637 million JP Yen), to Asians in Asia (10,710,170 million JP Yen), and to foreigners in $\operatorname{ROW}(3,132,287$ million JP Yen). There is no information on exports to foreigners in Asia or exports to Asians in ROW.

Value added earned by FAJF in Asia (8,054,035 million JP Yen) is calculated as sales minus purchases, which are available from METI (2002b). Assuming again that the ratio of value added to sales is the same no matter where the sales destination is, we obtain the value added by FAJF in goods and services sold to Japanese located in Japan (1,611,093 million JP Yen), to Japanese located in Asia (2,409,228 million JP Yen), to Japanese located in ROW (83,975 million JP Yen), to Asians located in Asia (3,613,841 million JP Yen), and to foreigners located in ROW (335,899 million JP Yen). Data are not available for sales by FAJF to Asians in Japan and ROW, or those to foreigners in Japan and ROW. Value added by FAJF in ROW in goods and services sold to various places is estimated in the same way.

METI (2002a) defines Japanese affiliates of foreign firms as those with foreign share of more than one-third. Therefore, exports of JAFFs in the analysis are those by such affiliates. METI (2002b) defines Japanese affiliates abroad as both "affiliates abroad" with no less than 10 percent ownership by Japanese parent firms and "affiliates of affiliates abroad" with more than $50 \%$ ownership by such "affiliates abroad" as mentioned above. Thus, sales and purchases by FAJFs in the analysis are those by such affiliates. In METI (2002b), it is known that exports in sales and imports in purchases by FAJFs are overstated because FAJFs are sometimes reported as exports/imports when they are selling local but the ultimate destinations/origins are foreign countries. We therefore regard 30 percent of sales and purchases to/from Japan and ROW in manufacturing as of local transactions. Moreover, there is no available 
information on the magnitude of transactions among FAJFs in METI (2002b). We therefore use $0.4(0.6)$ as a proxy of the ratio of sales to FAJFs (Asians) in local sales by FAJFs in Asia, 0.2 (0.8) as a proxy of the ratio of sales to FAJFs (foreigners) in sales to ROW by FAJFs in Asia, $0.4(0.6)$ as a proxy of the ratio of sales to FAJFs in Asia (Asians) in sales to Asia by FAJFs in ROW, and $0.2(0.8)$ as a proxy of the ratio of sales to FAJFs (foreigners) in local sales by FAJFs in ROW.

Since both METI (2002a) and METI (2002b) are approved statistics, the returned ratios are not so high. As for METI (2002a), 1,935 out of 3,742 parent firms returned the questionnaires (the returned ratio is 51.7 percent). In the case of METI (2002b), 2,157 out of 3,430 parent firms returned the questionnaires (the returned ratio is 62.9 percent), and the number of Japanese affiliates abroad covered is 14,991 . 


\begin{tabular}{|c|c|c|c|c|c|c|c|c|}
\hline & \multicolumn{2}{|c|}{ Exports } & \multicolumn{2}{|c|}{ Imports } & \multicolumn{2}{|c|}{ Exports } & \multicolumn{2}{|c|}{ Imports } \\
\hline & 1996 & 2000 & 1996 & 2000 & 1996 & 2000 & 1996 & 2000 \\
\hline & & & & & & & and & \\
\hline \multicolumn{9}{|l|}{ Value } \\
\hline Total (US\$1000) & $410,944,244$ & $479,244,574$ & $349,185,062$ & $379,661,760$ & $55,672,988$ & $68,780,636$ & $72,311,216$ & $61,445,996$ \\
\hline \multicolumn{9}{|l|}{ Share } \\
\hline of machinery goods in total & $74.9 \%$ & $74.9 \%$ & $28.1 \%$ & $32.0 \%$ & $40.3 \%$ & $45.6 \%$ & $50.4 \%$ & $47.1 \%$ \\
\hline of parts and components in total & $35.4 \%$ & $36.2 \%$ & $12.1 \%$ & $16.1 \%$ & $21.7 \%$ & $28.7 \%$ & $30.3 \%$ & $34.0 \%$ \\
\hline \multirow{2}{*}{ of parts and components in machinery goods } & $47.3 \%$ & $48.3 \%$ & $43.1 \%$ & $50.2 \%$ & $54.0 \%$ & $62.8 \%$ & $60.1 \%$ & $72.2 \%$ \\
\hline & \multicolumn{4}{|c|}{ Korea } & \multicolumn{4}{|c|}{ Philippines } \\
\hline Value & & & & & & & & \\
\hline Total (US\$1000) & $129,696,331$ & $172,264,221$ & $150,320,064$ & $160,477,507$ & $20,537,617$ & $38,072,479$ & $34,697,094$ & $33,802,416$ \\
\hline \multicolumn{9}{|l|}{ Share } \\
\hline of machinery goods in total & $54.2 \%$ & $59.6 \%$ & $40.9 \%$ & $41.4 \%$ & $58.7 \%$ & $77.4 \%$ & $53.8 \%$ & $54.1 \%$ \\
\hline of parts and components in total & $24.1 \%$ & $29.0 \%$ & $20.7 \%$ & $26.5 \%$ & $46.5 \%$ & $60.9 \%$ & $35.7 \%$ & $43.4 \%$ \\
\hline \multirow[t]{2}{*}{ of parts and components in machinery goods } & $44.5 \%$ & $48.7 \%$ & $50.6 \%$ & $64.0 \%$ & $79.1 \%$ & $78.7 \%$ & $66.4 \%$ & $80.2 \%$ \\
\hline & \multicolumn{4}{|c|}{ Hong Kong } & \multicolumn{4}{|c|}{ Indonesia } \\
\hline Value & & & & & & & & \\
\hline Total (US\$1000) & $180,914,323$ & $202,683,171$ & $201,282,410$ & $214,039,820$ & $49,811,786$ & $62,117,778$ & $42,923,875$ & $33,509,943$ \\
\hline \multicolumn{9}{|l|}{ Share } \\
\hline of machinery goods in total & $38.8 \%$ & $45.5 \%$ & $41.7 \%$ & $47.6 \%$ & $10.7 \%$ & $18.1 \%$ & $42.2 \%$ & $28.7 \%$ \\
\hline of parts and components in total & $19.5 \%$ & $27.0 \%$ & $20.2 \%$ & $28.7 \%$ & $4.4 \%$ & $9.3 \%$ & $21.7 \%$ & $15.7 \%$ \\
\hline \multirow[t]{2}{*}{ of parts and components in machinery goods } & $50.4 \%$ & $59.4 \%$ & $48.5 \%$ & $60.2 \%$ & $41.8 \%$ & $51.2 \%$ & $51.4 \%$ & $54.6 \%$ \\
\hline & \multicolumn{4}{|c|}{ Singapore } & \multicolumn{4}{|c|}{ China } \\
\hline \multicolumn{9}{|l|}{ Value } \\
\hline Total (US\$1000) & $122,882,738$ & $137,803,198$ & $131,337,708$ & $134,544,130$ & $151,046,318$ & $249,201,432$ & $138,831,036$ & $225,091,657$ \\
\hline \multicolumn{9}{|l|}{ Share } \\
\hline of machinery goods in total & $70.4 \%$ & $71.8 \%$ & $63.0 \%$ & $65.3 \%$ & $26.6 \%$ & $36.2 \%$ & $42.5 \%$ & $44.3 \%$ \\
\hline of parts and components in total & $36.8 \%$ & $45.7 \%$ & $39.0 \%$ & $46.0 \%$ & $10.0 \%$ & $15.3 \%$ & $19.2 \%$ & $28.1 \%$ \\
\hline \multirow[t]{2}{*}{ of parts and components in machinery goods } & $52.3 \%$ & $63.7 \%$ & $62.0 \%$ & $70.4 \%$ & $37.4 \%$ & $42.3 \%$ & $45.3 \%$ & $63.5 \%$ \\
\hline & \multicolumn{4}{|c|}{ Malaysia } & & & & \\
\hline Value & & & & & & & & \\
\hline Total (US\$1000) & $78,308,476$ & $98,224,808$ & $77,901,213$ & $81,287,187$ & & & & \\
\hline \multicolumn{9}{|l|}{ Share } \\
\hline of machinery goods in total & $57.3 \%$ & $64.4 \%$ & $62.7 \%$ & $66.0 \%$ & & & & \\
\hline of parts and components in total & $33.7 \%$ & $41.9 \%$ & $42.4 \%$ & $52.5 \%$ & & & & \\
\hline of parts and components in machinery goods & $58.9 \%$ & $65.0 \%$ & $67.7 \%$ & $79.5 \%$ & & & & \\
\hline
\end{tabular}

Data source: Authors' calculation, based on PC-TAS (UN Comtrade only for Hong Kong's exports). 
$\%$

Figure 1 Machinery goods and the parts and components: shares in total exports and imports in 2000

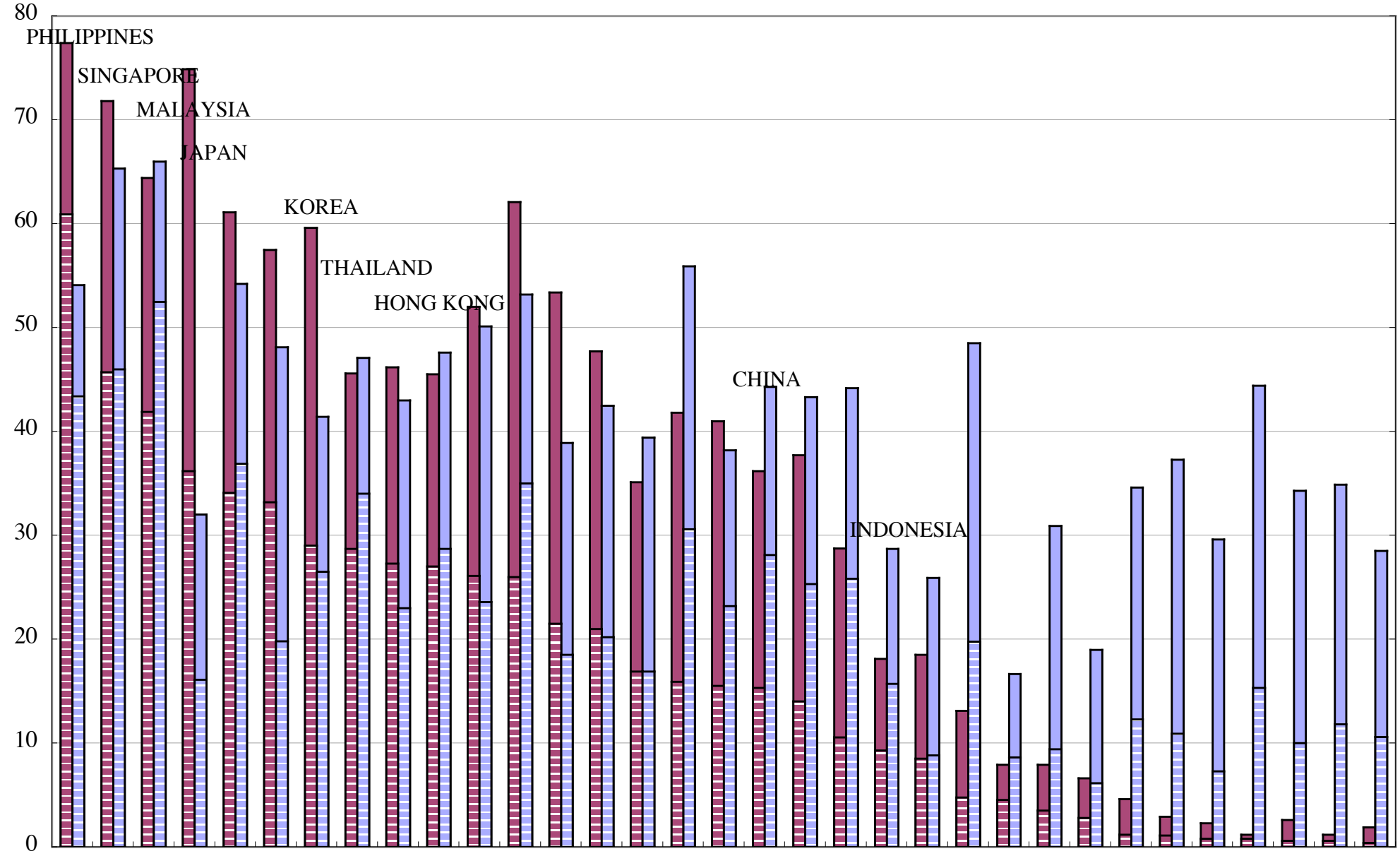

सि

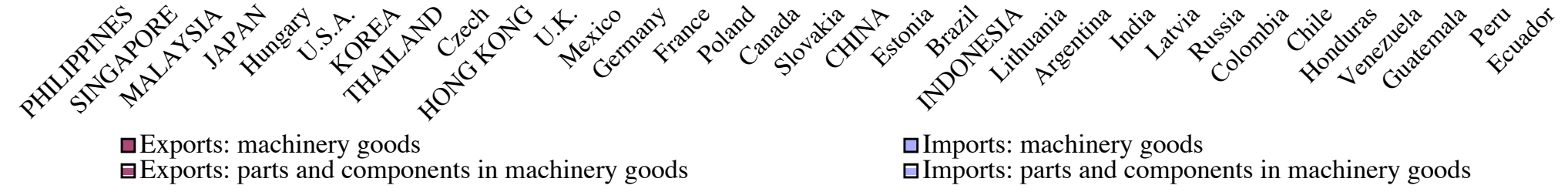

Data source: Authors' calculation , based on PC-TAS (UN Comtrade only for exports of Hong Kong and exports and imports of Russia and Slovakia). 
Table 2 Japanese Parent Firms and Foreign Affiliates by Industry, $2000 \mathrm{~F} / \mathrm{Y}$

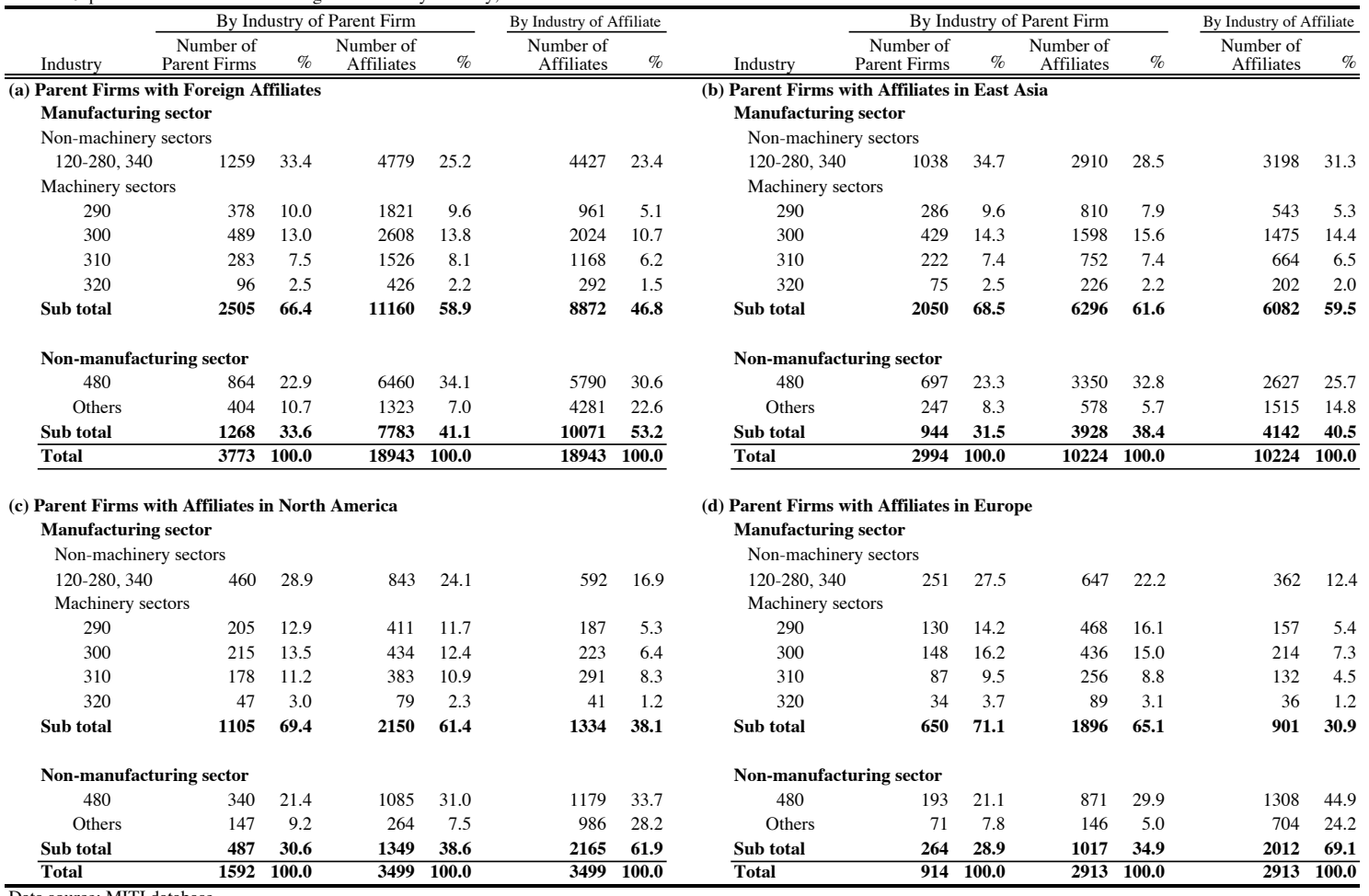

Data source: MITI database.

Notes: Others includes industries "050", "540", and "other". Number of affiliates for the cases (a), (b), (c), and (d) are the (a) number of foreign affiliates, (b) number of affiliates in East Asia, (c) number of affiliates in North America,
and (d) number of affiliates in Europe, respectively.

Table 3 Foreign Affiliate Ownership Patterns of Japanese Parent Firms, 2000 F/Y (Number of Parent Firms)

\begin{tabular}{|c|c|c|c|c|c|c|c|c|c|c|c|c|c|}
\hline \multirow{2}{*}{$\begin{array}{l}\text { Number of Regular } \\
\text { workers of Parent Firm }\end{array}$} & \multicolumn{12}{|c|}{ Number of Affiliates } & \multirow[b]{2}{*}{$\%$} \\
\hline & 1 & 2 & 3 & 4 & 5 & 6 & 7 & 8 & 9 & 10 & More & Total & \\
\hline & \multicolumn{12}{|c|}{ in East Asia } & \\
\hline 50 to 99 & 301 & 67 & 25 & 12 & 1 & 2 & 1 & . & . & . & 1 & 410 & 13.7 \\
\hline 100 to 199 & 413 & 101 & 34 & 23 & 7 & 1 & 2 & . & 2 & . & . & 583 & 19.5 \\
\hline 200 to 299 & 196 & 92 & 30 & 12 & 8 & 10 & 3 & 2 & 1 & . & 1 & 355 & 11.9 \\
\hline 300 to 499 & 242 & 99 & 36 & 28 & 18 & 8 & 6 & 4 & 2 & . & 4 & 447 & 14.9 \\
\hline 500 to 999 & 209 & 117 & 65 & 42 & 27 & 20 & 5 & 2 & 4 & 2 & 10 & 503 & 16.8 \\
\hline 1,000 and more & 136 & 107 & 77 & 54 & 55 & 45 & 27 & 38 & 16 & 19 & 122 & 696 & 23.2 \\
\hline \multirow[t]{2}{*}{ Total } & 1497 & 583 & 267 & 171 & 116 & 86 & 44 & 46 & 25 & 21 & 138 & 2994 & 100.0 \\
\hline & \multicolumn{12}{|c|}{ in North America } & \\
\hline 50 to 99 & 90 & 13 & 2 & . & . & . & . & . & . & 1 & . & 106 & 6.7 \\
\hline 100 to 199 & 185 & 14 & 2 & 1 & . & . & 1 & . & . & . & . & 203 & 12.8 \\
\hline 200 to 299 & 129 & 18 & 2 & . & . & . & . & . & . & . & . & 149 & 9.4 \\
\hline 300 to 499 & 183 & 30 & 10 & 2 & 1 & 2 & . & . & 1 & . & . & 229 & 14.4 \\
\hline 500 to 999 & 210 & 58 & 20 & 6 & 3 & 1 & 1 & 2 & . & . & 2 & 303 & 19.0 \\
\hline 1,000 and more & 271 & 126 & 69 & 39 & 28 & 17 & 10 & 7 & 7 & 1 & 27 & 602 & 37.8 \\
\hline \multirow[t]{2}{*}{ Total } & 1068 & 259 & 105 & 48 & 32 & 20 & 12 & 9 & 8 & 2 & 29 & 1592 & 100.0 \\
\hline & \multicolumn{12}{|c|}{ in Europe } & \\
\hline 50 to 99 & 26 & 2 & . & 1 & . & . & . & . & . & . & . & 29 & 3.2 \\
\hline 100 to 199 & 58 & 8 & 2 & 1 & . & . & . & . & . & . & . & 69 & 7.5 \\
\hline 200 to 299 & 43 & 11 & 2 & . & . & . & . & . & . & . & . & 56 & 6.1 \\
\hline 300 to 499 & 84 & 21 & 8 & 3 & 1 & 3 & . & . & . & . & . & 120 & 13.1 \\
\hline 500 to 999 & 113 & 24 & 16 & 4 & 2 & 2 & . & 1 & 1 & 1 & 3 & 167 & 18.3 \\
\hline 1,000 and more & 178 & 93 & 55 & 37 & 17 & 18 & 14 & 8 & 10 & 9 & 34 & 473 & 51.8 \\
\hline Total & 502 & 159 & 83 & 46 & 20 & 23 & 14 & 9 & 11 & 10 & 37 & 914 & 100.0 \\
\hline
\end{tabular}

Data source: MITI database. 
Table 4 Sector Switching Between Parent Firms and Their Affiliates in East Asia

(a) Industries of Japanese Parent Firms and Their Affiliates in East Asia, 2000 F/Y (number of affiliates in East Asia)

Industry of Affiliate in East Asia

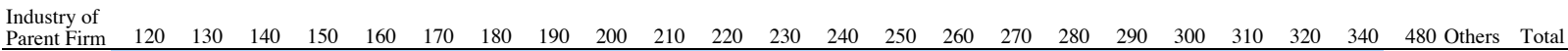

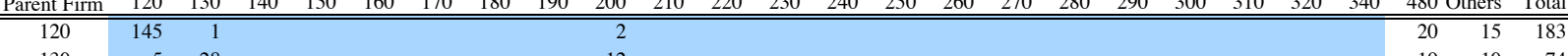

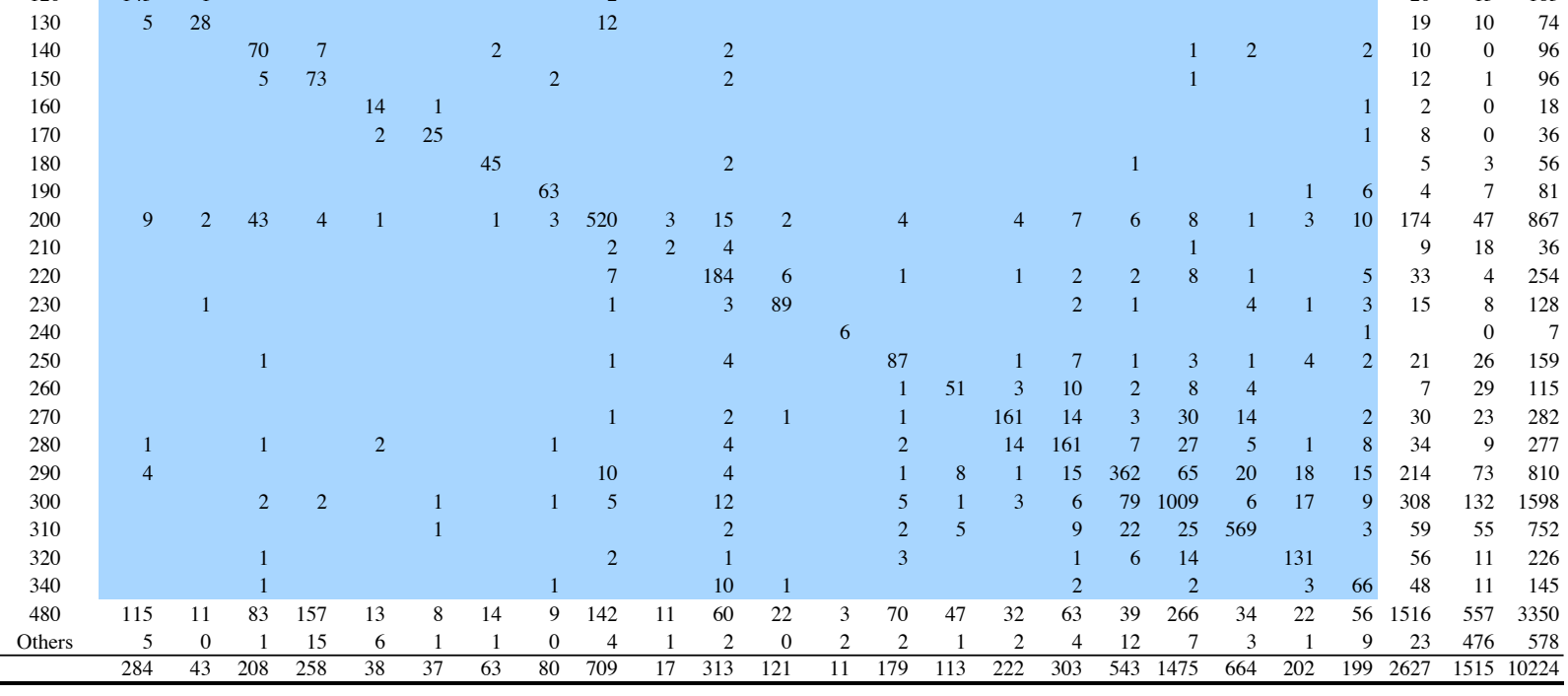

(b) Industries of Japanese Parent SMEs and Their Affiliates in East Asia, 2000 F/Y (number of affiliates in East Asia)

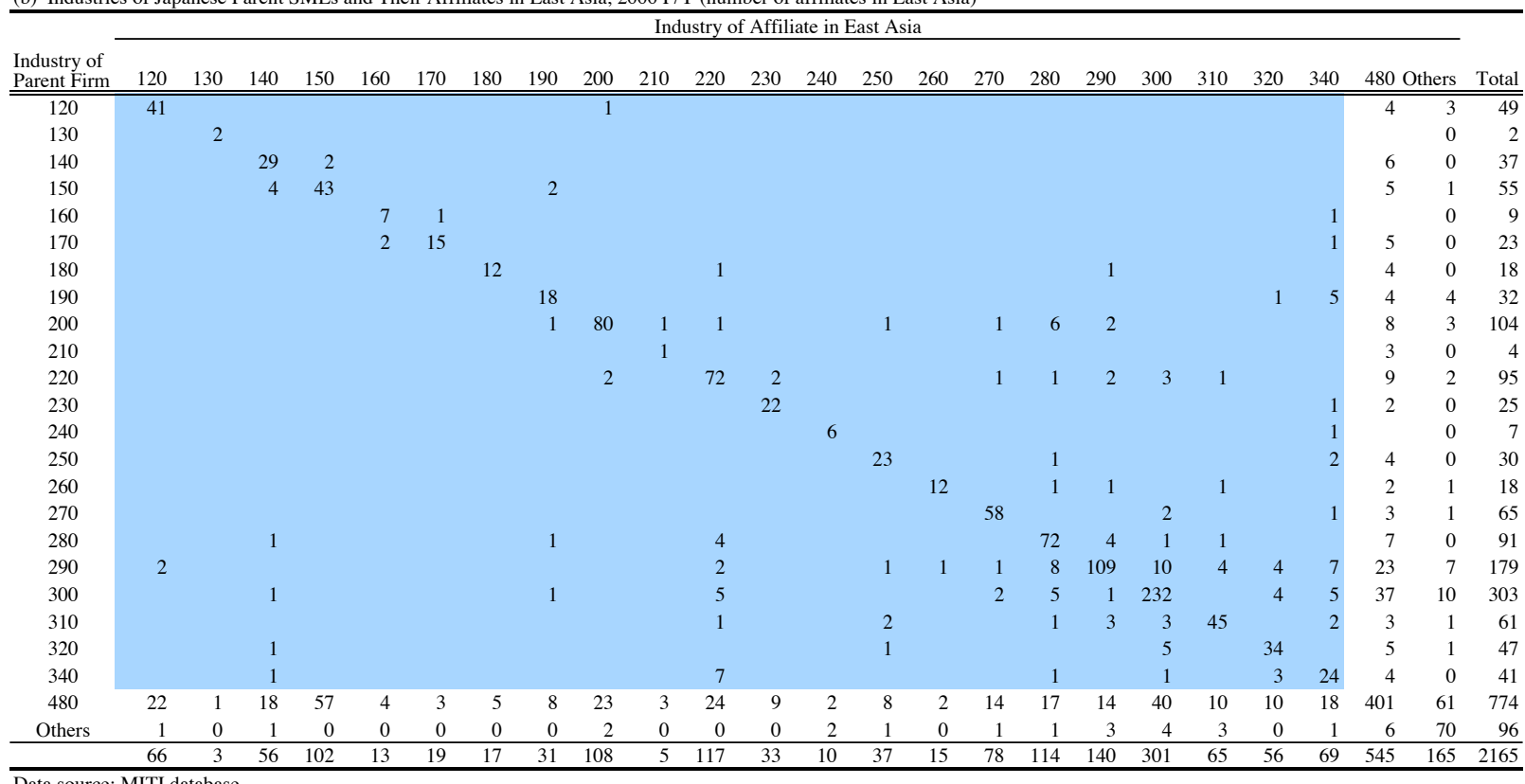

Data source: MITI database

Note: "Others" includes industries "050", "540", and "other". 
Table 5 Logit Estimation: Japanese Parent Firms, $1995 \mathrm{~F} / \mathrm{Y}$

\begin{tabular}{|c|c|c|c|c|}
\hline \multirow[b]{2}{*}{ Variable } & \multicolumn{4}{|c|}{ Dependent Variables } \\
\hline & $\begin{array}{l}\text { Foreign Affiliates: } \\
\text { with }=1 ; \text { without }=0\end{array}$ & $\begin{array}{l}\text { Affiliates in East Asia: } \\
\text { with }=1 ; \text { without }=0\end{array}$ & $\begin{array}{l}\text { Affiliates in North America: } \\
\text { with }=1 \text {; without }=0\end{array}$ & $\begin{array}{r}\text { Affiliates in Europe: } \\
\text { with }=1 \text {; without }=0\end{array}$ \\
\hline $\begin{array}{l}\text { (a) Parent Firms: All Sectors } \\
\text { (a) }\end{array}$ & $(1)$ & $(2)$ & $(3)$ & $(4)$ \\
\hline Constant & $\begin{array}{l}-5.547 * * * \\
(-42.82)\end{array}$ & $\begin{array}{l}-5.713 * * * \\
(-42.77)\end{array}$ & $\begin{array}{l}-8.302 * * * \\
(-45.23)\end{array}$ & $\begin{array}{l}-11.085 * * * \\
(-40.40)\end{array}$ \\
\hline Number of relgular workers $(\log )$ & $\begin{array}{l}0.694 * * * \\
(31.00)\end{array}$ & $\begin{array}{l}0.693 * * * \\
(30.22)\end{array}$ & $\begin{array}{l}0.960 * * * \\
(32.91)\end{array}$ & $\begin{array}{l}1.236 * * * \\
(30.83)\end{array}$ \\
\hline Tangible assets per regular workers & $\begin{array}{l}0.010 * * * \\
(6.55)\end{array}$ & $\begin{array}{l}0.003 * \\
(1.66)\end{array}$ & $\begin{array}{l}0.009 * * * \\
(5.10)\end{array}$ & $\begin{array}{l}0.007 * * * \\
(2.85)\end{array}$ \\
\hline Foreign sales: ratio to total sales & $\begin{array}{l}7.132 * * * \\
(25.06)\end{array}$ & $\begin{array}{l}5.146 * * * \\
(22.84)\end{array}$ & $\begin{array}{l}5.288 * * * \\
(23.61)\end{array}$ & $\begin{array}{l}5.564 * * * \\
(23.12)\end{array}$ \\
\hline$R \& D$ expenditure: ratio to total sales & $\begin{array}{l}9.565 * * * \\
(8.50)\end{array}$ & $\begin{array}{l}6.160 * * * \\
(6.02)\end{array}$ & $\begin{array}{l}12.479 * * * \\
(10.06)\end{array}$ & $\begin{array}{l}11.031 * * * \\
(8.51)\end{array}$ \\
\hline Advertisement expenditure: ratio to total sale & $\begin{array}{l}-0.122 \\
(-0.14)\end{array}$ & $\begin{array}{l}-1.546 \\
(-1.19)\end{array}$ & $\begin{array}{r}1.656 \\
(1.42)\end{array}$ & $\begin{array}{l}2.757 * \\
(1.92)\end{array}$ \\
\hline $\begin{array}{l}\text { Log likelihood } \\
\text { Number of observations }\end{array}$ & $\begin{array}{r}-5948.385 \\
13623\end{array}$ & $\begin{array}{r}-5425.176 \\
13623\end{array}$ & $\begin{array}{r}-3366.289 \\
13623\end{array}$ & $\begin{array}{r}-1823.668 \\
13623\end{array}$ \\
\hline (b) Parent Firms: Manufacturing Sector & $(1)^{\prime}$ & $(2)^{\prime}$ & $(3)^{\prime}$ & $(4)^{\prime}$ \\
\hline Constant & $\begin{array}{l}-5.769 * * * \\
(-35.19)\end{array}$ & $\begin{array}{l}-5.924 * * * \\
(-35.63)\end{array}$ & $\begin{array}{l}-8.302 * * * \\
(-37.83)\end{array}$ & $\begin{array}{l}-11.628 * * * \\
(-33.81)\end{array}$ \\
\hline Number of relgular workers $(\log )$ & $\begin{array}{l}0.775 * * * \\
(26.97)\end{array}$ & $\begin{array}{l}0.770 * * * \\
(26.74)\end{array}$ & $\begin{array}{l}1.078 * * * \\
(28.72)\end{array}$ & $\begin{array}{l}1.340 * * * \\
(26.60)\end{array}$ \\
\hline Tangible assets per regular workers & $\begin{array}{l}0.006 * * * \\
(2.93)\end{array}$ & $\begin{array}{l}0.000 \\
(0.09)\end{array}$ & $\begin{array}{l}0.010 * * * \\
(4.61)\end{array}$ & $\begin{array}{l}0.008 * * * \\
(2.77)\end{array}$ \\
\hline Foreign sales: ratio to total sales & $\begin{array}{l}6.200 * * * \\
(20.10)\end{array}$ & $\begin{array}{l}4.275 * * * \\
(17.61)\end{array}$ & $\begin{array}{l}4.899 * * * \\
(19.35)\end{array}$ & $\begin{array}{l}5.065 * * * \\
(18.26)\end{array}$ \\
\hline R\&D expenditure: ratio to total sales & $\begin{array}{l}6.3411^{* * *} \\
(5.51)\end{array}$ & $\begin{array}{l}3.469 * * * \\
(3.39)\end{array}$ & $\begin{array}{l}9.834 * * * \\
(7.48)\end{array}$ & $\begin{array}{l}9.265 * * * \\
(6.99)\end{array}$ \\
\hline Advertisement expenditure: ratio to total sale & $\begin{array}{l}0.846 \\
(0.79)\end{array}$ & $\begin{array}{l}-0.030 \\
(-0.03)\end{array}$ & $\begin{array}{r}2.570 \\
(1.60)\end{array}$ & $\begin{array}{l}1.798 \\
(1.56)\end{array}$ \\
\hline Log likelihood & -3994.629 & -3715.727 & -2291.635 & -1275.963 \\
\hline Number of observations & 8577 & 8577 & 8577 & 8577 \\
\hline $\begin{array}{l}\text { Data source: MITI database. } \\
\text { Notes: } \\
\text { Numbers in parentheses are t-statistics. } \\
* * * \text { Significant at the } 1 \text { percent level. } \\
* \quad \text { Significant at the } 10 \text { percent level. }\end{array}$ & & & & \\
\hline
\end{tabular}

Table 6 Intra-Regional Production Networks: Sales and Purchases by Japanese Affiliates in East Asia, 1998 F/Y

\begin{tabular}{|c|c|c|c|c|c|c|c|c|c|c|c|c|c|c|c|c|c|c|}
\hline \multirow{4}{*}{ Industry } & \multirow{4}{*}{$\begin{array}{c}\text { Number } \\
\text { of } \\
\text { Affiliate } \\
\text { s }\end{array}$} & \multirow{4}{*}{$\%$} & \multicolumn{8}{|c|}{ Sales } & \multicolumn{8}{|c|}{ Purchases } \\
\hline & & & \multirow{3}{*}{$\begin{array}{l}\text { Total Sales } \\
\text { (Million Yen) }\end{array}$} & \multirow{3}{*}{$\%$} & \multicolumn{6}{|c|}{ Share in Total Sales (\%) } & \multirow{3}{*}{$\begin{array}{c}\text { Total } \\
\text { Purchases } \\
\text { (Million Yen) }\end{array}$} & \multirow{3}{*}{$\%$} & \multicolumn{6}{|c|}{ Share in Total Purchases (\%) } \\
\hline & & & & & \multirow[t]{2}{*}{ Local } & \multirow[t]{2}{*}{ Japan } & \multicolumn{4}{|c|}{ Third Countries (Total) } & & & \multirow[t]{2}{*}{ Local } & \multirow[t]{2}{*}{ Japan } & \multicolumn{4}{|c|}{ Third Countries (Total) } \\
\hline & & & & & & & & $\begin{array}{l}\text { East } \\
\text { Asia } \\
\end{array}$ & $\begin{array}{c}\text { North } \\
\text { America }\end{array}$ & Europe & & & & & & $\begin{array}{l}\text { East } \\
\text { Asia }\end{array}$ & $\begin{array}{c}\text { North } \\
\text { America }\end{array}$ & Europe \\
\hline \multicolumn{19}{|c|}{ Manufacturing Sector } \\
\hline $120+130$ & 162 & 2.6 & 343929 & 1.5 & 69.1 & 16.2 & 14.7 & 6.4 & 3.3 & 3.5 & 137424 & 0.9 & 78.8 & 6.6 & 14.6 & 8.0 & 0.4 & 0.5 \\
\hline $140+150$ & 399 & 6.4 & 503397 & 2.2 & 43.6 & 30.2 & 26.1 & 12.2 & 4.9 & 7.4 & 254218 & 1.7 & 54.0 & 26.6 & 19.4 & 13.1 & 2.3 & 0.8 \\
\hline 160 & 23 & 0.4 & 17204 & 0.1 & 15.3 & 56.3 & 28.3 & 24.0 & 0.9 & 0.1 & 7818 & 0.1 & 94.0 & 2.7 & 3.3 & 0.0 & 0.0 & 3.3 \\
\hline 170 & 14 & 0.2 & 7073 & 0.0 & 52.8 & 34.3 & 12.9 & 8.8 & 4.0 & 0.0 & 4821 & 0.0 & 75.2 & 13.8 & 11.0 & 7.9 & 0.0 & 3.0 \\
\hline 180 & 36 & 0.6 & 50256 & 0.2 & 74.2 & 12.5 & 13.3 & 9.0 & 3.5 & 0.0 & 15328 & 0.1 & 62.5 & 20.5 & 17.0 & 14.1 & 1.8 & 1.1 \\
\hline 190 & 27 & 0.4 & 27536 & 0.1 & 77.8 & 0.4 & 21.8 & 11.5 & 0.4 & 5.5 & 2694 & 0.0 & 73.7 & 16.6 & 9.8 & 0.0 & 1.9 & 7.8 \\
\hline 200 & 529 & 8.5 & 1414684 & 6.1 & 69.8 & 6.7 & 23.5 & 15.7 & 5.0 & 1.5 & 579333 & 3.8 & 53.6 & 19.4 & 27.0 & 13.3 & 6.8 & 1.9 \\
\hline 210 & 17 & 0.3 & 36418 & 0.2 & 21.2 & 65.7 & 13.1 & 2.9 & 0.0 & 10.2 & 32061 & 0.2 & 21.7 & 18.0 & 60.4 & 45.4 & 10.3 & 3.9 \\
\hline 220 & 109 & 1.8 & 92230 & 0.4 & 64.7 & 20.1 & 15.2 & 9.7 & 1.7 & 2.9 & 38584 & 0.3 & 68.0 & 25.7 & 6.3 & 5.1 & 0.2 & 0.5 \\
\hline 230 & 54 & 0.9 & 107614 & 0.5 & 41.4 & 34.3 & 24.3 & 13.2 & 4.9 & 5.1 & 24259 & 0.2 & 57.4 & 23.6 & 19.0 & 17.1 & 0.3 & 1.6 \\
\hline 240 & 16 & 0.3 & 7196 & 0.0 & 4.5 & 21.2 & 74.3 & 22.5 & 44.0 & 7.8 & 5282 & 0.0 & 10.0 & 6.8 & 83.2 & 41.2 & 9.8 & 3.2 \\
\hline 250 & 160 & 2.6 & 334130 & 1.4 & 69.7 & 17.2 & 13.2 & 8.8 & 3.5 & 0.8 & 140533 & 0.9 & 41.3 & 31.5 & 27.2 & 23.1 & 3.3 & 0.5 \\
\hline 260 & 166 & 2.7 & 423491 & 1.8 & 85.4 & 2.9 & 11.7 & 6.5 & 2.6 & 0.1 & 229136 & 1.5 & 19.2 & 70.0 & 10.8 & 10.4 & 0.0 & 0.2 \\
\hline 270 & 110 & 1.8 & 281041 & 1.2 & 55.9 & 15.6 & 28.6 & 26.3 & 0.9 & 1.0 & 155313 & 1.0 & 44.1 & 31.7 & 24.2 & 19.0 & 0.3 & 1.1 \\
\hline 280 & 121 & 1.9 & 97240 & 0.4 & 70.9 & 13.4 & 15.7 & 11.9 & 1.9 & 1.4 & 47014 & 0.3 & 67.8 & 29.0 & 3.2 & 1.7 & 0.3 & 1.1 \\
\hline 290 & 315 & 5.1 & 688971 & 3.0 & 32.4 & 40.7 & 27.0 & 14.8 & 5.5 & 4.6 & 400705 & 2.6 & 57.7 & 32.2 & 10.1 & 8.8 & 0.8 & 0.4 \\
\hline 300 & 916 & 14.7 & 5191673 & 22.3 & 32.3 & 32.9 & 34.8 & 24.9 & 5.3 & 3.0 & 3711079 & 24.4 & 35.8 & 37.0 & 27.2 & 26.3 & 0.4 & 0.2 \\
\hline 310 & 478 & 7.7 & 2140129 & 9.2 & 81.0 & 11.1 & 7.9 & 2.2 & 3.5 & 1.5 & 1380996 & 9.1 & 53.4 & 37.2 & 9.4 & 6.1 & 2.5 & 0.7 \\
\hline 320 & 100 & 1.6 & 464375 & 2.0 & 27.2 & 45.9 & 26.9 & 23.1 & 1.5 & 2.0 & 271580 & 1.8 & 40.2 & 41.2 & 18.6 & 14.5 & 2.6 & 1.5 \\
\hline $330+340$ & 83 & 1.3 & 95985 & 0.4 & 22.3 & 63.6 & 14.1 & 2.8 & 7.5 & 2.9 & 63645 & 0.4 & 55.1 & 37.7 & 7.1 & 5.9 & 0.4 & 0.7 \\
\hline \multicolumn{19}{|c|}{ Non-Manufacturing Sector } \\
\hline 480 & 957 & 15.4 & 8524268 & 36.7 & 41.3 & 19.4 & 39.3 & 33.0 & 2.2 & 2.8 & 6333657 & 41.6 & 28.4 & 35.2 & 36.4 & 28.3 & 1.5 & 2.7 \\
\hline Others & 1421 & 22.9 & 2386309 & 10.3 & 77.7 & 11.2 & 11.1 & 8.0 & 1.5 & 1.2 & 1387281 & 9.1 & 72.7 & 19.5 & 7.8 & 5.5 & 1.1 & 0.6 \\
\hline Total & 6213 & $\frac{2.0}{100.0}$ & 23235149 & 100.0 & 49.6 & 21.9 & 28.4 & 21.2 & 3.4 & 2.6 & 15222761 & 100.0 & 41.1 & 33.4 & 25.5 & 20.7 & 1.5 & 1.3 \\
\hline
\end{tabular}

Data source: MITI database.

Note: "Others" includes industries "050", "540", and "other". 
Figure 2 Japanese value added embodied in sales to Asians and foreigners by Japanese: Three-country setting (2000)

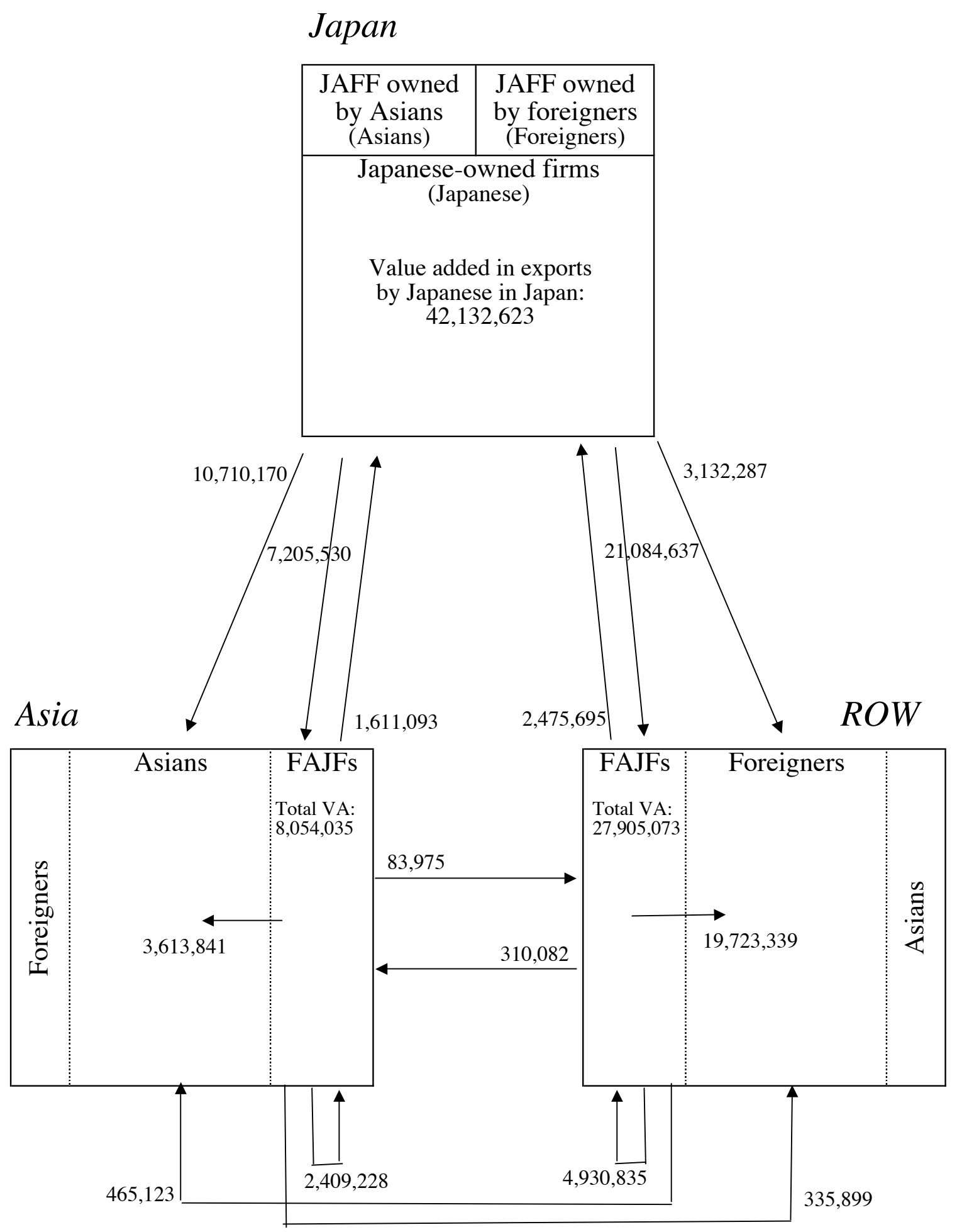

Data source: Table A.3. 
Table 7 Major Channels for Japanese Firms to Sell Products Abroad

(Unit: Million JP Yen)

2000

Note: minor indirect channels such as "to produce in Japan and to distribute through FAJF in ROW and then through FAJF in Asia" are omitted.

Data source: the above figures are estimated based on Table A.3.

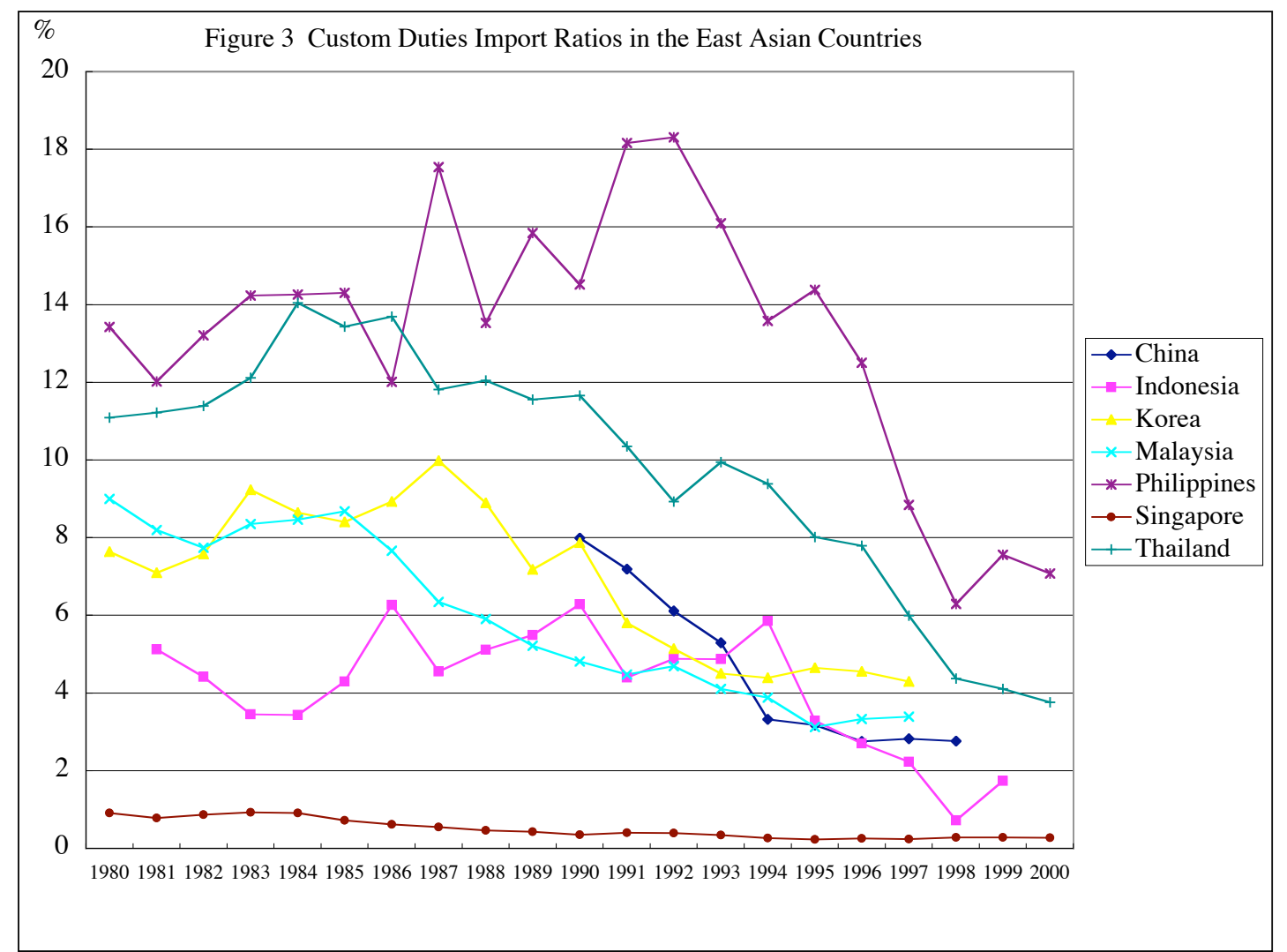

Drawn from Ando and Estevadeordal (2003) (Original data source: World Bank Indocators 2002 (CD-ROM)). 
Table A.1 Definition of Parts and Components

\begin{tabular}{l}
\hline HS classification \\
\hline \hline $840140,840290,840390,840490,840590,8406,8407,8408,8409,8410,8411,8412,8413,8414$ \\
, 841520, 841590, 8416, 8417, 841891, 841899, 841990, 842123, 842129, 842131, 842191, 84219 \\
$9,842290,842390,842490,8431,843290,843390,843490,843590,843680,843691,843699,84$ \\
$3790,843890,843991,843999,844090,844190,844240,844250,844390,8448,845090,845190$ \\
$, 845240,845290,845390,845490,845590,8466,846791,846792,846799,846890,8473,84749$ \\
0, 847590, 847690, 847790, 847890, 847990, 8480, 8481, 8482, 8483, 8484, 8485, 8503, 850490, \\
$8505,850690,8507,850890,850990,851090,8511,8512,851390,851490,851590,851690,851$ \\
$790,8518,8522,8529,853090,8531,8532,8533,8534,8535,8536,8537,8538,8539,8540,854$ \\
$1,8542,854390,8544,8545,8546,8547,8548,8607,8706,8707,8708,870990,8714,871690,8$ \\
$803,8805,9001,9002,9003,900590,900691,900699,900791,900792,900890,900990,901090$ \\
$, 901190,901290,9013,9014,901590,901790,902490,902590,902690,902790,902890,90299$
\end{tabular}

Table A.2 Industry Classification

Manufacturing sector

\begin{tabular}{ll}
120 & Food processing \\
130 & Beverages, tobacco, and animal feed \\
140 & Textiles \\
150 & Apparel \\
160 & Wood and wood products \\
170 & Furniture and fixures \\
180 & Pulp, paper, and paper products \\
190 & Publishing and printing \\
200 & Chemicals \\
210 & Petroleum and coal products \\
220 & Plastic products \\
230 & Pubber products \\
240 & Leather and leather products \\
250 & Ceramics, clay, and stone products \\
260 & Iron and steel \\
270 & Nonferrous metal \\
280 & Metal products \\
290 & General machinery \\
300 & Electric machinery \\
310 & Transport equipment \\
320 & Precision machinery \\
330 & Arms \\
340 & Other manufacturing \\
& \\
\hline
\end{tabular}

290+300+310+320 Machinery sector

Non-manufacturing sector

$\begin{array}{cl}050 & \text { Mining } \\ 480 & \text { Wholesale trade } \\ 540 & \text { Retail trade } \\ \text { Other } & \text { Services and other }\end{array}$




\begin{tabular}{|c|c|c|c|c|}
\hline \multirow{2}{*}{\multicolumn{2}{|c|}{ Category }} & \multicolumn{3}{|c|}{2000} \\
\hline & & \multirow{2}{*}{$\begin{array}{l}\text { Exports } \\
\mathbf{4 6 , 0 4 8 , 5 9 6}\end{array}$} & \multirow{2}{*}{$\begin{array}{r}\text { Value-added (VA) } \\
\mathbf{4 2 , 1 3 2 , 6 2 3}\end{array}$} & \multirow{2}{*}{$\begin{array}{r}\%) \\
100.0\end{array}$} \\
\hline [1] & Japanese value added in exports of Japanese-owned firms in Japan & & & \\
\hline$[1-1]$ & In exports to FAJFs (Japanese) & $30,919,567$ & $28,290,167$ & \\
\hline$[1-1-1]$ & located in Asia & $7,875,240$ & $7,205,530$ & 17.1 \\
\hline$[1-1-2]$ & located in ROW & $23,044,326$ & $21,084,637$ & 50.0 \\
\hline [1-2] & In exports to Asians (non-Japanese) & $11,705,616$ & $10,710,170$ & \\
\hline$[1-2-1]$ & located in Asia & $11,705,616$ & $10,710,170$ & 25.4 \\
\hline$[1-2-2]$ & located in ROW & n.a. & n.a. & \\
\hline$[1-3]$ & In exports to foreigners (non Japanese\&Asian) & $3,423,414$ & $3,132,287$ & \\
\hline$[1-3-1]$ & located in Asia & n.a. & n.a. & \\
\hline$[1-3-2]$ & located in ROW & $3,423,414$ & $3,132,287$ & 7.4 \\
\hline [2] & Value added by FAJFs in Asia & $36,376,123$ & $8,054,035$ & 100.0 \\
\hline$[2-1]$ & In goods and services sold to Japanese & $18,537,086$ & $4,104,295$ & \\
\hline$[2-1-1]$ & located in Japan & $7,276,515$ & $1,611,093$ & 20.0 \\
\hline$[2-1-2]$ & located in Asia (other FAJFs in Asia) & $10,881,299$ & $2,409,228$ & 29.9 \\
\hline$[2-1-3]$ & located in ROW (other FAJFs in ROW) & 379,272 & 83,975 & 1.0 \\
\hline$[2-2]$ & In goods and services sold to Asians (non-Japanese) & $16,321,948$ & $3,613,841$ & \\
\hline [2-2-1] & located in Japan & n.a. & n.a. & \\
\hline$[2-2-2]$ & located in Asia & $16,321,948$ & $3,613,841$ & 44.9 \\
\hline$[2-2-3]$ & located in ROW & n.a. & n.a. & \\
\hline$[2-3]$ & In goods and services sold to foreigners (non Japanese\&Asian) & $1,517,089$ & $28,240,972$ & \\
\hline [2-3-1] & located in Japan & n.a. & $27,905,073$ & \\
\hline$[2-3-2]$ & located in Asia & n.a. & n.a. & \\
\hline$[2-3-3]$ & located in ROW & $1,517,089$ & 335,899 & 4.2 \\
\hline [3] & Value added by Japanese affiliates in ROW & $92,638,856$ & $27,905,073$ & 100.0 \\
\hline$[3-1]$ & In goods and services sold to Japanese & $25,617,494$ & $7,716,611$ & \\
\hline$[3-1-1]$ & located in Japan & $8,218,775$ & $2,475,695$ & 8.9 \\
\hline$[3-1-2]$ & located in Asia (other FAJFs in Asia) & $1,029,405$ & 310,082 & 1.1 \\
\hline$[3-1-3]$ & located in ROW (other FAJFs in ROW) & $16,369,314$ & $4,930,835$ & 17.7 \\
\hline [3-2] & In goods and services sold to Asians (non-Japanese) & $1,544,107$ & 465,123 & \\
\hline$[3-2-1]$ & located in Japan & n.a. & n.a. & \\
\hline$[3-2-2]$ & located in Asia & $1,544,107$ & 465,123 & 1.7 \\
\hline$[3-2-3]$ & located in ROW & n.a. & n.a. & \\
\hline [3-3] & In goods and services sold to foreigners (non Japanese\&Asian) & $65,477,255$ & $19,723,339$ & \\
\hline [3-3-1] & located in Japan & n.a. & n.a. & \\
\hline$[3-3-2]$ & located in Asia & n.a. & n.a. & \\
\hline [3-3-3] & located in ROW & $65,477,255$ & $19,723,339$ & 70.7 \\
\hline
\end{tabular}

Definition:

FAJF: Foreign affiliates of Japanese firms that include "affiliates abroad" with no less than 10 percent ownership by Japanese . parent firms and "affiliates of affiliates abroad" with more than $50 \%$ ownership by such "affiliates abroad".

JAFF: Japanese affiliates of foreign firms with foreign share of more than one-third.

ROW: All countries other than Japan and Asia (region).

Japanese: Households and governments in Japan + all firms located in Japan - JAFF + FAJF .

Households and governments in Asia + Asian-owned firms located in Asia. + affiliates of firms owned by Asians in Asians: Japan and ROW .

Foreigners:Households and governments in ROW + foreign-owned firms located in ROW + affiliates of foreign firms in Japan and Asia 
Method of estimation:

1. ([Japanese total exports] - [Exports by JAFF] $) \times(1-0.08504)=[1-1]+.[1-2]+.[1-3$.

1-1. [1-1-1.]+[1-1-2.]

1-1-1. ([Imports from Japan by FAJF in Asia] - [Imports from JAFF by FAJF in Asia (n.a.)]) x (1 - 0.08504)

1-1-2. ([Imports from Japan by FAJF in ROW] - [Imports from JAFF by FAJF in ROW (n.a.)]) x (1 - 0.08504)

1-2. $\quad[1-2-1]+.[1-2-2$. $]$

1-2-1. ([Japanese exports to Asia] - [Exports to Asia by JAFF (available only for exports to Asia)]) x (1 - 0.08504) - [1-1-1.] - [1-3-1.]

1-2-2. [Japanese exports to p.c. nationals located in ROW (n.a.)] x (1 - 0.08504)

$1-3$. [1-3-1.] $+[1-3-2$.

1-3-1. [Japanese exports to foreigners located in Asia (n.a.)] x $(1-0.08504)$

1-3-2. ([Japanese exports to ROW] - [Exports to ROW by JAFF]) x (1 - 0.08504) - [1-1-2.] - [1-2-2.]

2. [Sales by FAJF in Asia] $-[$ Purchases by FAJF in Asia] $=[2-1]+.[2-2]+.[2-3$. $]$

2-1. [2-1-1.] + [2-1-2.]+ [2-1-3.]

2-1-1. [2.] x [Ratio of sales to Japan by FAJF in Asia] - [2-2-1.] - [2-3-1.]

2-1-2. [2.] x ([Ratio of local sales by FAJF in Asia] $x$ [Ratio of sales to FAJF in local sales by FAJF in Asia (proxy: 0.4)]

2-1-3. [2.] x ([Ratio of sales to ROW by FAJF in Asia] $x$ [Ratio of sales to FAJF in ROW in sales to ROW by FAJF in Asia (proxy: 0.2)]

2-2. $[2-2-1]+.[2-2-2]+.[2-2-3$. $]$

2-2-1. [Value added in goods and services sold to JAFF (owned by Asians) by FAJF in Asia (n.a.)]

2-2-2. [2.] x [Ratio of local sales by FAJF in Asia] x [Ratio of sales to Asians in local sales by FAJF in Asia (proxy: 0.6)]- [2-1-2.] - [2-3-2.]

2-2-3. [Value added in goods and services sold to Asians located in ROW by FAJF in Asia (n.a.)]

2-3. [2-3-1.] + [2-3-2.]+[2-3-3.]

2-3-1. [Value added in goods and services sold to JAFF (owned by foreigners) by FAJF in Asia (n.a.)]

2-3-2. [Value added in goods and services sold to foreigners located in Asia by FAJF in Asia (n.a.)]

2-3-3. [2.] x [Ratio of sales to ROW by FAJF in Asia]x [Ratio of sales to foreigners in sales to ROW by FAJF in Asia (proxy: 0.8)] - [2-1-3.] - [2-2-3.]

3. [Sales by FAJF in ROW] - [Purchases by FAJF in ROW] $=[3-1]+.[3-2]+.[3-3$.

3-1. [3-1-1.] + [3-1-2.]+[3-1-3.]

3-1-1. [3.] x [Ratio of sales to Japan by FAJF in ROW] - [3-2-1.] - [3-3-1.]

3-1-2. [3.] x ([Ratio of sales to Asia by FAJF in ROW] x [Ratio of sales to FAJF in Asia in sales to Asia by FAJF in ROW (proxy: 0.4)]

3-1-3. [3.] $x$ ([Ratio of local sales by FAJF in ROW] $x$ [Ratio of sales to FAJF in local sales by FAJF in ROW (proxy: 0.2)]

3-2. [3-2-1.] + [3-2-2.]+[3-2-3.]

3-2-1. [Value added in goods and services sold to JAFF (owned by Asians) by FAJF in ROW (n.a.)]

3-2-2. [3.] x [Ratio of sales to Asia by FAJF in ROW]x [Ratio of sales to Asians in sales to Asia by FAJF in ROW (proxy: 0.6)] - [3-1-2.] - [3-3-2.]

3-2-3. [Value added in goods and services sold to Asians located in ROW by FAJF in ROW (n.a.)]

3-3. [3-3-1.] + [3-3-2.]+[3-3-3.]

3-3-1. [Value added in goods and services sold to JAFF (owned by foreigners) by FAJF in ROW (n.a.)]

3-3-2. [Value added in goods and services sold to foreigners located in Asia by FAJF in ROW (n.a.)]

3-3-3. [3.] x ([Ratio of local sales by FAJF in ROW] x [Ratio of sales to foreigners in sales to ROW by FAJF in ROW (proxy: 0.8]) - [3-1-3.] - [3-2-3.]

Data sources: METI (2001) for exports of Japan; METI (2002a) for exports of JAFF; MITI (2002b) for sales and purchases of FAJF. Management and Coodination Agency (1999, pp.406) for the import inducement coefficient of export in Japan for 1995: 0.08504. 